\title{
Investors' heterogeneous beliefs and the impact of sovereign credit ratings in foreign exchange and equity markets
}

Article

Accepted Version

Tran, V., Alsakka, R. and ap Gwilym, O. (2019) Investors' heterogeneous beliefs and the impact of sovereign credit ratings in foreign exchange and equity markets. European Journal of Finance, 25 (13). pp. 1211-1233. ISSN 1466-4364 doi: https://doi.org/10.1080/1351847X.2019.1586743 Available at https://centaur.reading.ac.uk/88901/

It is advisable to refer to the publisher's version if you intend to cite from the work. See Guidance on citing.

To link to this article DOI: http://dx.doi.org/10.1080/1351847X.2019.1586743

Publisher: Taylor and Francis

All outputs in CentAUR are protected by Intellectual Property Rights law, including copyright law. Copyright and IPR is retained by the creators or other copyright holders. Terms and conditions for use of this material are defined in the End User Agreement.

www.reading.ac.uk/centaur 
Central Archive at the University of Reading

Reading's research outputs online 


\title{
Investors' heterogeneous beliefs and the impact of sovereign credit ratings in foreign exchange and equity markets
}

\author{
Vu Tran ${ }^{\mathrm{a}, *}$, Rasha Alsakka ${ }^{\mathrm{b}}$, and Owain ap Gwilym ${ }^{\mathrm{b}}$ \\ ${ }^{a}$ School of Management, Swansea University, Swansea, SA1 8EN, UK. \\ ${ }^{b}$ Bangor Business School, Bangor University, Bangor, LL57 2DG, UK.
}

\section{This version: $4^{\text {th }}$ January 2019}

\begin{abstract}
We propose a model in which sovereign credit news from multiple rating agencies interacts with market heterogeneity. The model illustrates that the first messenger discloses new information while additional messengers play an important role of coordinating heterogeneous beliefs. Empirical investigations based on sovereign credit ratings, foreign exchange and equity markets confirm that rating news coordinates investors' beliefs. Sovereign credit rating news from both types of messenger induces a significant impact on exchange rates and stock indices. Volatility measures increase in response to news from the first messenger while ex-post volatility reduces following news from an additional messenger.
\end{abstract}

JEL classification: G14; G15; G24

Keywords: Sovereign credit ratings, Information content, Market heterogeneity, Price volatility.

\footnotetext{
* Corresponding author. Tel.: +44 (0) 1792 513130. E-mail address: v.tran@swansea.ac.uk
} 


\section{Introduction}

Credit rating agencies (CRAs), such as Fitch, Moody’s Investors Service (Moody’s), and Standard and Poor's (S\&P), distil information into a rating to represent an issuer's creditworthiness. While there is prior literature on the impact of credit rating news (e.g. Boot et al., 2006; Bongaerts et al., 2012; Adelino and Ferreira, 2016), this paper contributes to the debate by proposing a model for the interaction between multiple sovereign credit ratings and market heterogeneity. The subsequent empirical investigations support the model's predictions that rating news coordinates investors' heterogeneous beliefs.

Credit ratings are heavily used in financial markets and regulation. Accessing capital markets is a key reason for issuers to solicit credit ratings from CRAs. EU and US regulations allow the use of credit ratings to assess banks' capital adequacy (e.g. the Basel III Accord) and for oversight of permitted investments by some institutions. The internal investment policies in many companies require a specific rating threshold as a condition to invest. However, the US sub-prime crisis and European sovereign debt crisis triggered increased scrutiny of the relative performance of CRAs, and instigated a renewed debate on the informativeness of credit ratings and the role that CRAs should play in the global financial system. CRAs were viewed as guilty of assigning excessively high ratings on structured securities, which had a significant impact on the US sub-prime crisis and its consequences (e.g. Mathis et al, 2009). In contrast, criticism of CRAs during the European sovereign debt crisis was more focused on the extent and timing of sovereign credit rating downgrades of several euro-zone governments. Therefore, issues relating to sovereign ratings, corporate ratings and structured finance ratings should be considered separately. In response to the role of CRAs in the global financial crisis, the EU and the US enacted reforms of the rating industry in 2009 and 2010, respectively. Both EU and US CRA regulations seek to reduce the mechanistic reliance on CRAs and hence to reduce market overreactions to credit rating actions. In addition, there has been a focus in the recent academic 
literature on the performance of CRAs (e.g. Adelino and Ferreira, 2016; Drago and Gallo; 2016; Hill et al., 2018). Since our paper focuses on the market impact of first-move sovereign credit rating news and additional-move rating news (see below), our findings have clear implications and should attract interest from participants including policy makers, investors, issuers and CRAs. ${ }^{1}$

Typically, multiple CRAs assess the creditworthiness of a given debt issuer/issue. Consequently, there is a degree of repetition in the information content embedded in rating actions from different CRAs. The research question focuses on whether all types of sovereign credit rating news are informative in this multiple-rating context. A key innovation in our model is to divide sovereign credit rating actions into two categories: (i) actions that reveal a new CRA opinion about the rated issuer's creditworthiness; and (ii) actions that reaffirm prevailing CRA opinions. We term the former as first-move rating news and the latter as additional-move rating news. Furthermore, we disentangle the mechanism behind the information value from multiple CRAs.

Heterogeneous beliefs play a crucial role in explaining many empirical features of financial markets (e.g. Anderson et al, 2005; Li and Muzere, 2010). Proposing an interaction between multiple-CRAs' opinions and investors' heterogeneous beliefs, our model yields testable hypotheses on how investors react to sovereign credit rating news. The homogeneous beliefs hypothesis implies that market participants may not respond to the additional-move rating news. Alternatively, the heterogeneous beliefs hypothesis yields three predictions: (i) financial asset prices react to both types of rating news; (ii) asset price volatility increases in response to first-move rating news because the news increases ex-ante uncertainty and ex-post disagreement between investors regarding the true level of the rated issuer's creditworthiness;

\footnotetext{
${ }^{1}$ Sovereign credit rating actions have attracted particular recent attention. IMF (2010) highlights that sovereign default was the most pressing risk facing the global economy, with indebted European countries causing widespread concerns. More details on the importance of sovereign credit ratings are discussed in Section 2.2.
} 
(iii) reductions in asset price volatility could follow additional-move rating news because this reassures market participants, hence reduces the heterogeneity in investors' beliefs.

The empirical investigations are conducted in the context of sovereign credit ratings, foreign exchange (FX) and stock markets. The information content of sovereign credit rating actions has wide implications (e.g. Dittmar and Yuan, 2008; Adelino and Ferreira, 2016), while FX and equity markets account for a high proportion of global financial activity and typically incorporate new information very quickly (e.g. BIS, 2016). Empirical investigations on FX and stock index returns and volatility can reveal robust evidence on the information content of sovereign credit rating news, given the high trading volume and the sophisticated participants in these markets.

Related literature mainly focuses on the impact of sovereign credit rating news from individual CRA(s) on the prices of financial assets (e.g. Gande and Parsley, 2005; Boot et al., 2006; Adelino and Ferreira, 2016). In contrast, this paper investigates multiple dimensions of price and volatility reactions. ${ }^{2}$ We employ a number of measures, including abnormal returns, realized volatility (RV) based on intraday data to estimate ex-post disagreement among investors, and option-implied volatility (IV) as a measure of ex-ante uncertainty.

A comprehensive sample of the largest three CRAs' sovereign credit ratings on all countries which adopt a floating FX regime (covering 41 countries) during the period from January 2007 to April 2013 is used. We find evidence in support of hypotheses pertaining to heterogeneous beliefs. First, we report that both first-move and additional-move sovereign credit rating actions have a significant impact on FX rates and stock indices. For example, a 1notch first-move (additional-move) downgrade of a AAA/Aaa rated sovereign induces a 120 (75) basis-point currency depreciation against the US\$. Second, we find that both ex-ante uncertainty and ex-post disagreement among investors increase in response to first-move

\footnotetext{
${ }^{2}$ Papers on multiple ratings primarily focus on investigations of split ratings and their impacts (e.g. Bongaerts et al., 2012).
} 
sovereign credit rating news. This directly indicates a strong degree of heterogeneity in market reactions or investors' beliefs towards an item of information. Third, there are different reactions of the volatility measures following additional-move sovereign credit rating news. For the full sample, ex-post volatility reduces significantly while ex-ante volatility does not react to additional-move sovereign credit rating news. However, for a sub-sample of EU countries, ex-ante volatility also reduces significantly in these cases.

Further, we provide additional evidence by investigating whether the above results vary with different types of rating news. IMF (2010) states that most of the informational value from CRAs arises through outlook/watch procedures rather than actual rating level changes. Consistent with the heterogeneous beliefs hypothesis, we find: (i) (even 1-notch) sovereign credit downgrades following outlook/watch procedures are still informative. FX rates and stock indices react to both first-move and additional-move sovereign credit downgrades of issuers who were previously on negative outlook/wachlist; (ii) volatility measures increase in response to first-move rating news of such downgrades; (iii) volatilities reduce in response to additionalmove news of such downgrades. The robustness of the findings is strengthened by Monte Carlo experiments and by controlling for the macroeconomic fundamentals.

Taken together, the results demonstrate the importance of multiple messengers in the sovereign credit rating market. Informative rating news is not exclusively from the first messenger, and news from additional messengers plays an important role in coordinating investors' heterogeneous beliefs. The findings are relevant to regulators in the context of the debate surrounding increased competition among CRAs (e.g. SEC, 2011).

The paper is organised as follows. Section 2 reviews related literature, Section 3 proposes the model and testable hypotheses. Section 4 describes the data and methodology for the empirical investigations. Sections 5 and 6 present the empirical results and conclusions. 


\section{Literature review}

\subsection{Market heterogeneity, asset prices, and credit ratings}

Investors' heterogeneous beliefs play an important role in asset pricing. Prior literature reveals that market heterogeneity can explain many empirical features of asset prices including price bubbles and crashes (e.g. Hong and Stein, 2003), breadth of ownership and returns (e.g. Chen et al., 2002), and volatility spill-over effects of shocks (e.g. Li and Muzere, 2010). Dynamic heterogeneity models in which asset pricing is based on a stochastic discount factor can also explain empirical features of asset prices and volume (e.g. Buraschi and Jiltsov, 2006). Heterogeneous beliefs can lead to mispricing and increased price volatility because an asset's price can deviate from its fundamental value, both in the short- and long-term. Therefore, market heterogeneity links to uncertainty about risk, which is a potential factor in asset pricing (e.g. Anderson et al., 2005; Buraschi and Jiltsov, 2006).

Another strand of literature shows that credit ratings play an important role in uncertainty reduction. Boot et al. (2006) show that credit ratings act as a focal point, and fulfil a monitoring role that mitigates the multiple equilibria problem. However, they argue that the coordination role of credit ratings only exists hand in hand with a contractual commitment between the CRA(s) and the rated issuer(s). An and Chan (2008) and Jory et al (2016) reveal that similar situations present in IPO and M\&A deals.

\subsection{The market impact of sovereign credit ratings}

The sovereign credit rating business is dominated by three global players: Fitch, Moody's and S\&P (ESMA, 2016). Recent regulatory reforms in Europe and the US advocate increasing competition in the industry. However, there is surprisingly little published evidence that compares the performance of the existing CRAs (e.g. Hill et al., 2010). The sovereign credit rating acts as a ceiling on non-sovereigns' ratings (e.g. Adelino and Ferreira, 2016; Almeida et 
al., 2017; Hill et al., 2018). Sovereign bond yields typically act as indicators of sovereign risk, and movements in corporate bond yields are correlated to innovations in sovereign yields (Dittmar and Yuan, 2008). Sovereign credit ratings are also found to significantly affect international bank loans (Kim and Wu, 2011), equity investments (Gande and Parsley, 2005) and foreign direct investment flows (e.g. Cai et al., 2018). Further, a certification role of ratings (see e.g. Bongaerts et al., 2012) implies huge regulatory costs associated with sovereign credit rating actions. Given investors' international diversification and the close linkages between sovereign credit risk and domestic firms, the information content of sovereign credit rating news extends far beyond the rated government's securities.

Prior empirical studies demonstrate that sovereign credit ratings are a key element influencing asset price movement. This implies that the CRAs hold private information which is released into the public domain through credit announcements. Prior studies find strong and significant relationships between sovereign credit rating downgrades and a country's equity market return, FX rates, bond spreads and credit default swap (CDS) spreads, while upgrades have a limited impact (see Kaminsky and Schumkler, 2002; Sy 2004; Hill and Faff, 2010; Ismailescu and Kazemi, 2010; Afonso et al., 2012). In addition, negative sovereign credit events induce significant spillovers to other countries' equity, bond, CDS and FX markets, particularly in neighbouring countries and during crisis periods (see Gande and Parsley, 2005; Ferreira and Gama, 2007; De Santis, 2014; Drago and Gallo; 2016). A government could have an incentive to leak the possibility of a positive credit change soon after any favourable discussions with a CRA (Gande and Parsley, 2005). In contrast, negative events tend to have a larger surprise component and thus are more informative because of the absence of an incentive for an issuer to leak negative news prior to a CRA's announcement. Another possible explanation could be the stronger negative reputational impacts for a CRA being tardy in the case of negative events (Alsakka and ap Gwilym, 2013). 
Previous literature also shows that different CRAs' sovereign credit rating actions trigger different market responses (e.g. Hill and Faff, 2010; Afonso et al., 2012; Alsakka and ap Gwilym, 2013). In addition, disagreements across CRAs on their assessment of sovereigns' creditworthiness are very common (e.g. Vu et al., 2017). CRAs use different models and consider different quantitative and qualitative factors and place different weights on these factors. CRAs also demonstrate a number of policy differences in terms of rating accuracy, rating stability, and the timing of their announcements (e.g. S\&P, 2014; Moody’s, 2015; Fitch, 2017). Therefore, rating news from different CRAs regarding the same underlying information will not always enter the public domain simultaneously. A degree of repetition in rating information from multiple CRAs is also inevitable. Part of our innovative approach is to divide rating news into two groups regardless of which CRA released the news. CRA actions that reveal new information regarding the rated issuer's creditworthiness are considered here as first-move rating news while news that reaffirms the former is termed additional-move rating news.

The closely related literature primarily focuses on the reactions of financial assets' prices (i.e. bond yield spreads, CDS spread, abnormal stock returns, FX rates) to news from individual CRA(s) (e.g. Gande and Parsley, 2005; Ferreira and Gama, 2007; Ismailescu and Kazemi, 2010; Hill et al., 2018). Alternatively, some researches have eliminated 'contaminated' events where multiple CRAs release sovereign credit rating actions within a specified time window. This approach again ignores the relative importance of different rating actions and time sequences. Such approaches implicitly assume that investors do not possess nor consider other CRAs' opinions. This paper contributes to prior literature by investigating whether the information content is exclusively embedded in the 'first-move' type of rating news. Additional-move rating news could play an important role in aiding the market consensus because a strong degree of heterogeneity in market perceptions inevitably exists. 


\section{The model and hypotheses}

Assume that the time-varying latent credit quality of a given issuer is $\theta_{t}$ and there are $n$

CRAs in the market.

At time $t$, each CRA publicises an estimation of the issuer creditworthiness:

$$
\widehat{\theta}_{t}^{l}=\varphi_{t}^{i}+\vartheta_{t}^{i} \quad \forall i=1 . . n
$$

Where: $\varphi_{t}^{i} \sim$ i.i.d $\left(\theta_{t}, \sigma_{\theta_{t}}^{2}\right)$ captures the unbiased element in the CRA's estimation.

$$
\vartheta_{t}^{i} \sim \text { i. i. } d\left(0, \sigma_{\vartheta}^{2}\right) \text { denotes the biasedness in the CRA's estimation. }{ }^{3}
$$

Therefore, public information at time $t$ regarding the latent creditworthiness is an interval estimate, $\mathrm{I}_{\mathrm{t}}$ :

$$
\mathrm{I}_{\mathrm{t}}=\left[\operatorname{Min}\left(\widehat{\theta}_{t}^{l}\right), \operatorname{Max}\left(\widehat{\theta}_{t}^{l}\right)\right] \quad \forall i=1 . . n
$$

An unbiased and more efficient estimator of $\theta_{t}$ compared to any $\widehat{\theta}_{t}^{l}$ is

$$
\overline{\hat{\theta}_{t}}=\frac{\sum \widehat{\theta_{t}^{l}}}{n}=\overline{\varphi_{t}^{l}}+{\overline{\vartheta_{t}^{l}}}^{2}
$$

This indicator captures the agreed component across the CRAs regarding the issuer's creditworthiness. The variation in CRAs' opinions, i.e. $\overline{\hat{\theta}_{t}}-\operatorname{Min}\left(\widehat{\theta}_{t}^{l}\right)$ captures the disagreement component or the ambiguity regarding the issuer's latent creditworthiness.

Assume that there are Q units of the issuer's financial assets. Each investor produces his/her own valuation $(\mathrm{V})$ based on the information from a CRA of his/her choice i.e. the valuation is a monotonic function of the rated issuer's creditworthiness, ceteris paribus

$$
V_{t}^{i}=f\left(\hat{\theta}_{t}^{i}\right) \text { where } f^{\prime}\left(\hat{\theta}_{t}^{i}\right)>0
$$

Assume that there are two main groups of investors who have a constant-absolute-riskaversion (CARA) utility function with risk tolerances of $\beta_{\mathrm{A}}$ and $\beta_{\mathrm{B}}$, respectively.

\footnotetext{
${ }^{3}$ A CRA might be biased at time $t$, but it is debatable whether the bias is systematic i.e. for all CRAs. Besides, the bias tends to predominate for ratings on complex structured products and when these ratings dominate a CRA's revenues (e.g. Mathis et al., 2009). Our focus is on sovereign credit ratings, which are less prone to conflicts of interest and are potentially more accurate (e.g. Cornaggia et al., 2017).
} 
(i) Group A: rational investors believe that $\overline{\hat{\theta}}_{t}$ is the indicator of the issuer's creditworthiness. Their valuation of the asset would be $V_{t}=f\left(\overline{\hat{\theta}}_{t}\right)$. $V_{t}$ could be considered as fair fundamental value.

(ii) Group B: conservative investors believe that $\operatorname{Min}\left(\widehat{\theta_{t}^{\mathrm{l}}}\right)$ is the indicator of the latent creditworthiness although it is a downward biased estimator of $\theta_{\mathrm{t} .}{ }^{4}$ Their valuation of the asset would be

$$
V_{t}^{\text {biased }}=f\left(\operatorname{Min}\left(\widehat{\theta}_{t}^{l}\right)\right)=f\left(\overline{\hat{\theta}}_{t}^{l}\right)-H_{t}=V_{t}-H_{t} \text { where } H_{t}>0
$$

Where $H_{t}$ measures the degree of undervaluation by the group of conservative investors. The undervaluation is affected by the market heterogeneity driven by the ambiguity regarding the latent creditworthiness.

At $\mathrm{t}+1$, CRA $k$ announces a sovereign credit rating downgrade of the issuer which reveals new information into the public domain regarding the issuer's latent creditworthiness ${ }^{5}$ :

$$
\begin{gathered}
\mathrm{I}_{\mathrm{t}+1} \not \equiv \mathrm{I}_{\mathrm{t}} \\
\Leftrightarrow \quad \hat{\theta}_{t+1}^{k} \notin\left[\operatorname{Min}\left(\widehat{\theta}_{t}^{l}\right), \operatorname{Max}\left(\widehat{\theta}_{t}^{l}\right)\right] \\
\Rightarrow \quad \Delta \quad \Delta \overline{\hat{\theta}}_{t+1}=\frac{\widehat{\theta}_{t+1}^{k}-\widehat{\theta}_{t}^{k}}{n}<0 \\
\Rightarrow \quad \operatorname{Min}\left(\hat{\theta}_{t+1}^{i}\right)<\operatorname{Min}\left(\hat{\theta}_{t}^{i}\right)
\end{gathered}
$$

We regard this rating news as first-move because there is new credit information which was not publicly available at $t$.

At $t+2$, CRA $l$ announces a sovereign credit rating downgrade of the same issuer. For ease of exposition, assume that $\hat{\theta}_{t+2}^{l} \in\left[\operatorname{Min}\left(\hat{\theta}_{t+1}^{l}\right), \operatorname{Max}\left(\hat{\theta}_{t+1}^{l}\right)\right]$ otherwise we repeat the Equations (4), (6), (7). This leads to:

\footnotetext{
${ }^{4}$ Another group of investors who use $\operatorname{Max}\left(\widehat{\theta}_{t}^{l}\right)$ could be modelled. This is much less likely in the context of rating usage (see e.g. Bongaerts et al., 2012). Also, it is trivial and does not alter the model generalisation.

${ }^{5}$ We only use downgrades in our model for the sake of brevity and because investors tend to be more concerned about downgrades. Including sovereign credit rating upgrades does not affect the model generalisation.
} 


$$
\begin{gathered}
\mathrm{I}_{t+2} \equiv \mathrm{I}_{t+1} \\
\Delta \overline{\hat{\theta}}_{t+2}=\frac{\widehat{\theta}_{t+2}^{l}-\widehat{\theta}_{t+1}^{l}}{n}<0 \\
\operatorname{Min}\left(\hat{\theta}_{t+2}^{i}\right)=\operatorname{Min}\left(\hat{\theta}_{t+1}^{i}\right) \\
\overline{\hat{\theta}}_{t+2}-\operatorname{Min}\left(\hat{\theta}_{t+2}^{i}\right)<\overline{\hat{\theta}}_{t+1}-\operatorname{Min}\left(\hat{\theta}_{t+1}^{i}\right)
\end{gathered}
$$

We refer to this type of sovereign credit rating action as additional-move rating news because there is no new information regarding the underlying creditworthiness added to prevailing public information. CRA $l$ simply confirms other CRAs' opinions.

We make two competing assumptions about investors' beliefs or how investors react to credit rating news. Under the assumption that the market is homogeneous, the model predicts:

- If Group A of rational investors dominates the market, Equations (6) and (9) indicate that both types of rating news are informative.

- If Group B of conservative investors are the main players who drive market movements, Equations (7) and (10) indicate that only first-move rating news is informative. Financial asset prices only react to first-move rating news (i.e. at $t+1$ ).

Alternatively, the heterogeneous beliefs assumption implies that both groups of investors could drive the market movements i.e. the multiple valuations exist. Applying the utility function maximization, the demands for the asset by each group of investors would be $\beta_{\mathrm{A}}\left(\mathrm{V}_{\mathrm{t}}-\mathrm{P}\right)$ and $\beta_{\mathrm{B}}\left(\mathrm{V}_{\mathrm{t}}-\mathrm{H}_{\mathrm{t}}-\mathrm{P}\right)$, respectively. Imposing the market clearing condition, we have:

$$
\beta_{A}\left(\mathrm{~V}_{t}-\mathrm{P}\right)+\beta_{B}\left(\mathrm{~V}_{t}-H_{t}-\mathrm{P}\right)=Q
$$

Where P and Q denotes the clearing price and supply of the asset, respectively.

$$
\rightarrow P=V_{t}-\frac{\beta_{B}}{\beta_{A}+\beta_{B}} H_{t}-\frac{Q}{\beta_{A}+\beta_{B}}
$$


Equation (12) shows that the price depends not only on the fundamental valuation $\left(V_{t}\right)$ but also the level of market heterogeneity which is in turn driven by the ambiguity regarding the issuer's creditworthiness. ${ }^{6}$

Following prior papers on the relationship between heterogeneous beliefs and asset pricing (e.g. Chen et al., 2002; Xiong and Yan, 2010), we assume that

$$
H_{t}=h V_{t} \text { where } h \in[0,1)
$$

$h$ measures the degree of market heterogeneity regarding the true valuation and independent to $V_{t}$. This leads to the following equations:

$$
\begin{gathered}
P=V_{t}\left[1-\frac{\beta_{B}}{\beta_{A}+\beta_{B}} h\right]-\frac{Q}{\beta_{A}+\beta_{B}} \\
\operatorname{Var}(P)=\operatorname{Var}\left(V_{t}\right)\left[1+\frac{\beta_{B}^{2}}{\left(\beta_{A}+\beta_{B}\right)^{2}} h^{2}\right]
\end{gathered}
$$

Equation (13) shows that price volatility is greater than the volatility of the fundamental value. In other words, there is an additional element in price volatility due to the degree of market heterogeneity driven by the ambiguity regarding the latent creditworthiness. The greater the ambiguity, the larger the additional volatility.

$$
\begin{gathered}
\frac{\partial P}{\partial V_{t}}=1-\frac{\beta_{B}}{\beta_{A}+\beta_{B}} h>0 \\
\frac{\partial P}{\partial h}=-\frac{\beta_{B}}{\beta_{A}+\beta_{B}} V_{t}<0 \\
\frac{\partial^{2} P}{\partial h \partial V_{t}}=-\frac{\beta_{B}}{\beta_{A}+\beta_{B}}<0
\end{gathered}
$$

Equations (14) - (16), respectively, reflect the following features: (i) price increases when the fundamental value increases; (ii) price reduces with respect to the degree of ambiguity

\footnotetext{
${ }^{6}$ This valuation equation allows us to focus on the main idea of the interaction between market heterogeneity and rating actions. However, asset prices may also include a bubble element, e.g. imprecise signals or investors' overconfidence. In a more complex version (available upon request), we add another variable to capture bubbles in investors' valuations. In the context of sovereign rating actions, the solution for this alternative proves to be very similar to the simpler model reported in the paper.
} 
regarding the issuer's credit quality; (iii) the magnitude of the impact of the ambiguity on price is larger for high levels of creditworthiness.

Equations (6), (9), (14) and (16) imply that both types of negative sovereign credit rating news should trigger significant reductions in asset price. First-move negative rating news reduces the fundamental value and increases the level of ambiguity, thus the price should decline significantly. Additional-move sovereign credit rating news reduces both fundamental value and market heterogeneity. However, the impact on the former outweighs the impact on the latter i.e. as in Equation (16).

$$
\frac{\partial \operatorname{Var}(P)}{\partial h}=\operatorname{Var}\left(V_{t}\right)\left(2 \frac{\beta_{B}^{2}}{\left(\beta_{A}+\beta_{B}\right)^{2}} h\right)>0
$$

Equation (17) shows that a greater degree of market heterogeneity leads to higher asset price volatility. Therefore, there should be significant movements in price volatility in response to both first-move and additional-move sovereign credit rating news. Price volatility should increase (decrease) in response to first-move (additional-move) rating news. Higher volatility is intuitive as a significant change in the price during the announcement day should increase the volatility measures. The market movements should be short-lived. Meanwhile, the volatility reduction at $t+2$ is attributed to the reduction in ambiguity surrounding the latent creditworthiness. It is noteworthy that price changes during $t+2$ should raise realized volatility. Overall, changes in volatility could be insignificant. Nonetheless, any reduction in volatility following additional-move sovereign credit rating news indicates much more homogeneous beliefs i.e. an important role of market coordinator.

It is plausible that investors may not view all CRAs with equal credibility. In other words, some investors only consider a subset of $\widehat{\theta}_{t}^{l} \forall i=1 . . m<n$ and m may vary across investors. This leads to more than two groups of investors and strengthens the above predictions 
because additional-move sovereign credit rating news bridges even more gaps between groups of investors with heterogeneous beliefs. ${ }^{7}$

Overall, the model yields the following testable hypotheses: If homogeneous beliefs prevail, we should discover the following evidence:

$\mathrm{H}_{1}$ : First-move sovereign credit rating news triggers significant movements in prices. Additional-move sovereign credit rating news may not trigger significant price reactions.

$\mathrm{H}_{2}$ : Volatility increases in response to first-move sovereign credit rating news. Additional-move sovereign credit rating news does not trigger volatility reductions.

Alternatively, if heterogeneous beliefs prevail, we anticipate observing the following evidence:

$\mathrm{H}_{3}$ : Both types of sovereign credit rating news trigger significant movements in prices.

$\mathrm{H}_{4}$ : Volatility increases after sovereign credit first-move rating news whereas volatility reduces following additional-move rating news.

\section{Data and Methodology}

\subsection{Data}

We test the hypotheses using sovereign credit ratings, FX and stock markets. The dataset is an unbalanced panel which covers 41 countries during the period from January 2007 to April 2013 as listed in Table 1. We include all countries whose currencies are named in BIS (2016) except for the following nine: China, Hong Kong, Saudi Arabia, and Denmark whose FX

\footnotetext{
${ }^{7}$ In the model, we implicitly assume that markets are efficient at least in the semi-strong form. Therefore, market participants react in a timely manner to all public information. In our context, investors react in a timely manner to all sovereign rating announcements. Nonetheless, we acknowledge that a market might not comply with neither semi-strong nor strong forms of informational efficiency. Market participants might only follow subsets of CRAs (e.g., in line with Bianchi and Jehiel's (2015) model of extrapolation from subsets of public signals). This would lead to more than two groups of investors and development of a more complex model which can be solved in a similar way.
} 
regimes are categorised as (crawling) pegged/fixed in at least one version of the IMF de facto classifications; Canada, Norway, Singapore, Sweden, Switzerland who did not experience any sovereign credit rating actions by the three CRAs during the sample period. ${ }^{8}$

At the beginning of the sample period, the CRAs disagreed on the creditworthiness of most of the sampled sovereigns except for some AAA/Aaa-rated cases i.e. Austria, Finland, France, Germany, Luxembourg, Spain, and the UK. Later in the sample period, almost all of these were downgraded, leading to additional and longer-lasting disagreements between the CRAs. This fact implies that an interval estimate, rather than a point estimate, of a given sovereign's creditworthiness was available to market participants prior to many rating events (which is relevant for our model).

\subsubsection{Sovereign credit ratings}

Daily observations of long-term foreign-currency credit ratings, outlook and watch status of sovereigns rated by Fitch, Moody's, and S\&P are sourced from the CRAs' publications. We convert sovereign credit ratings to numerical scores on a 58-point comprehensive credit rating (CCR) scale in order to capture information on both actual ratings and outlook/watch procedures. ${ }^{9}$ In the CCR scale, rating symbols are converted as follows: $\mathrm{AAA} / \mathrm{Aaa} \equiv 58, \mathrm{AA}+/ \mathrm{Aa} 1 \equiv 55, \mathrm{AA} / \mathrm{Aa} 2 \equiv 52 \ldots \mathrm{CCC}-/ \mathrm{Caa} 3 \equiv 4, \mathrm{CC}-\mathrm{D} \equiv 1$. Adjustments for (positive/negative) outlook and watch signals are made by adding \pm 1 and \pm 2 , respectively. Nonlinearity in the rating scale is plausible, which means that the differences between rating levels

\footnotetext{
${ }^{8}$ US $\$$ is used as the reference currency given its dominance in international trades i.e. $88 \%$ of global FX trades (BIS, 2016). Therefore, USA is not included in the list of sample countries. The USA credit rating remains AAA/Aaa during most of the sample period. In August 2011, S\&P downgraded USA to AA+ while Moody's and Fitch kept their ratings at Aaa/AAA until the end of the sample period (with negative outlook from August and November 2011, respectively).

${ }^{9} \mathrm{~A}$ complete CRA credit opinion on an issuer consists of a credit rating and a rating outlook/watch status. Outlook and watch signals are at least as important as actual rating changes in terms of the impact on financial markets (e.g. Ferreira and Gama (2007); Hill and Faff (2010)). Using a rating scale that incorporates rating, outlook and watch is common in sovereign credit rating literature (e.g. Sy, (2004), Gande and Parsley (2005), Ferreira and Gama (2007), Alsakka and ap Gwilym (2013), Vu et al. (2017)).
} 
are not equal. Historical observations on default rates across rating categories suggest nonlinearity in the rating scale (see e.g. IMF, 2010; S\&P, 2013). In order to control for this, we employ a logit-transformation of the rating scale, as follows:

$$
L C C R= \begin{cases}\ln \left[\frac{C C R}{29-C C R}\right] & \forall C C R \in[1 . .28] \\ \ln \left[\frac{(C C R-28) *(C C R+28)^{\sqrt{\pi}}}{59-C C R}\right] & \forall C C R \in[29 . .58]\end{cases}
$$

Table 2 demonstrates the transformation of the alphabetical ratings to CCR and LCCR numerical scores and the varying effect of a given rating action across the levels of creditworthiness. It is reasonable for creditworthiness changes to be more significant when relating to near-default or AAA/Aaa rated issuers (e.g. as evidenced by the reactions to rating downgrades of France, UK, and USA in 2011-2013). The speculative threshold is also of critical concern to rating users, regulators, and investment guidelines (e.g. Bongaerts el al., 2012). For example, the U.S. Investment Company Act of 1940 restricts pension funds and municipalities to investment-grade securities (e.g. SEC, 2011). Our log-transformation of the rating scale addresses this issue by assigning greater weight for creditworthiness changes to issuers at or near (i) triple-A; (ii) default; (iii) the speculative-investment threshold (and assigning the lowest weight when sovereign credit rating news relates to issuers in the middle of the investmentgrade or the middle of the speculative-grade).

Table 3 summarises the sovereign credit rating events for each CRA. The CRAs released 521 rating events during the sample period for the selected sovereigns. S\&P released 202 signals while there are 166 (153) rating signals by Moody's (Fitch). During the sample period, there are 38 (47), 19 (36), 28 (38) positive (negative) outlook signals ${ }^{10}$ for the sample countries by S\&P, Moody's, and Fitch, respectively. The corresponding figures of watch actions are 7

\footnotetext{
${ }^{10}$ Outlook signals are defined as follows. Negative (positive) outlook signals include placing a sovereign on negative (positive) outlook and changing positive (negative) to stable outlook. Watch signals are defined similarly.
} 
(27), 12 (23), and 3 (14). During the sample period, the CRAs released 59 combined rating signals whereby sovereign credit rating level and outlook/watch changes were announced in the same action. All S\&P downgrades follow negative outlook or watch while the corresponding proportions for Moody's and Fitch are $90 \%$ and $87 \%$, respectively. The equivalent figures for upgrades are $70 \%, 89 \%$, and $52 \%$. These figures imply heavy utilisation of outlook/watch procedures prior to actual sovereign credit rating changes during the sample period.

A key innovation here is to separate first-move from additional-move sovereign credit rating actions. For every day during the sample period, the maximum difference across the three CRAs' opinions (i.e. CCR values on the same sovereign) is measured. This captures the variation or the boundary of credit information which is available to the market before rating events. If any sovereign credit rating action increases the maximum difference (i.e. a new assessment of the rated entity's creditworthiness falls beyond the boundary), it is defined as first-move news. Otherwise, it is recorded as additional-move rating news. ${ }^{11}$ During the sample period, the three CRAs release 174 first-move actions and 285 additional-move actions. ${ }^{12}$ Among the three CRAs, S\&P released 90 first-move signals compared to 44 and 40 from Fitch and Moody's, respectively. The corresponding numbers of additional-move rating actions are quite similar across the CRAs, ranging from 93 to 98 . The numbers of additional-move rating signals, thus, exceed first-move counterparts for each CRA. This implies a limitation in prior literature on the information content of rating news from a single CRA or from multiple CRAs treated individually. A significant proportion of sovereign credit rating actions from any given

\footnotetext{
${ }^{11}$ There were only nine days when more than one CRA released credit actions on the same sovereign. In these cases, only one action is counted as either a first-move or an additional-move while other CRAs' actions in the same days are excluded from the sample. The rule is applied in these cases that negative (positive) news from the most conservative (generous) CRA is retained.

${ }^{12}$ The number of first-move and additional-move actions together is less than the total number of signals from the three CRAs because we discard 62 rating actions where rating signals occurred on the same days i.e. 59 signals in cases of combined rating actions; and three signals during nine multiple-CRA-action days.
} 
CRA could simply repeat the information embedded in recent actions by other CRAs. Investigations based on an individual CRA do not separate potentially more "informative" firstmove news from others, thus, could yield limited or even misleading insights.

\subsubsection{FX data}

The dataset of bilateral FX rates against the US\$ covers all currencies named in BIS (2016) during January 2007 to April 2013 (apart from exceptions named at the beginning of Section 4.1). The sample includes 17 EU countries using the Euro, which enter the sample when they started using the Euro. ${ }^{13}$ All the sampled countries are categorised as having free floating or floating FX regimes in every IMF de facto classification since the classification began in 2006. ${ }^{14}$ The final data covers 41 countries and major currencies that account for approximately 90\% of global FX market trades (authors' estimates based on BIS, 2016). Daily data of midquoted FX rates is retrieved from DataStream (the primary source is Thomson Reuters).

We use two measures of FX volatility. First, realized volatility (RV) based on intraday data. RV represents the ex-post variance of intraday log-returns on a given day under the assumption that prices follow a semi-martingale process (Andersen et al., 2003a), and therefore measures the degree of heterogeneity in investors' beliefs within a given trading day. Second, option-implied volatility (IV) captures the FX option market participants' expected volatility of future FX rates. IV represents ex-ante uncertainty about the value of a currency against the US\$. One-month maturity at-the-money (ATM) option-implied volatility (IV) is employed for the empirical investigations. ${ }^{15}$

\footnotetext{
${ }^{13}$ All EU countries are included from the beginning of the sample period except Cyprus and Malta from January 2008, Slovakia from January 2009, Estonia from January 2011.

${ }^{14}$ There are two exceptions (Malaysia and Russia) categorised in "Other managed arrangement" in the IMF de facto classifications in 2010 and 2012. This category is a residual and is used when the exchange rate arrangement does not meet the criteria for any of the other categories.

${ }^{15}$ Investigations on IVs for other maturities (i.e. 3-, 6-month, 1-year) produce qualitatively similar results (available upon request).
} 
Daily RV data is collected from Bloomberg. ${ }^{16} \mathrm{RV}$ is estimated based on 30-minute frequency spot FX rates using the following formula: ${ }^{17}$

$$
R V_{t}=\sqrt{\sum_{k=1}^{48} r_{k, t}^{2}}
$$

$\mathrm{RV}_{\mathrm{t}}$ is $\mathrm{FX}$ realized volatility at day $\mathrm{t}$, and $\mathrm{r}_{\mathrm{k}, \mathrm{t}}$ is the $\mathrm{k}^{\text {th }} 30$-minute $\mathrm{FX} \log$-return at day $\mathrm{t}$.

There are 58,994 daily RV observations with mean, median, and standard deviation of $-0.0021,-0.0468$, and 5.2871, respectively. ${ }^{18}$

Daily data of mid-quoted OTC FX 1-month maturity ATM IV is retrieved from DataStream. There are 64,715 daily observations of one-month FX IV. The daily changes in IV have a mean of -0.0013 , median of 0 , and standard deviation of $0.7962 .{ }^{19}$

The standard deviation of daily changes in RV is almost seven times larger than for IV. This implies higher sensitivity of RV to news during the sample period (consistent with some prior studies e.g. Christensen and Prabhala, 1998). This is entirely reasonable because RV captures ex-post volatility or market participants' intraday disagreements, whereas 1-month IV measures the expected volatility or market participants' ex-ante uncertainty over a much longer period, i.e. with a horizon of the following month.

\subsubsection{Equity data}

The dataset covers national stock indices for the same 41 countries during the period from January 2007 to April 2013. Daily data of closing, intraday low and high prices for the sampled stock indices is retrieved from DataStream.

\footnotetext{
${ }^{16}$ Bloomberg started providing RV based on intraday data from March 2007. Therefore, the dataset of RV covers the period from March 2007 to April 2013 compared to January 2007 to April 2013 for IV.

17 Andersen et al. (2003a) use the 30-minute frequency as a suitable balance between the accuracy of RV measurement and avoiding market microstructure frictions.

${ }^{18} 1 \%$ winsorisation $(0.5 \%$ each tail) is used to mitigate the effects of outliers.

${ }^{19} \mathrm{As}$ for RV, $1 \%$ winsorisation is used.
} 
Stock volatility is captured by the intraday high-low range (Parkinson, 1980). The range is estimated as follows:

$$
\text { Range }_{i, t}=\frac{1}{2 \sqrt{\ln 2}} \ln \left(\frac{\operatorname{High}_{i, t}}{\operatorname{Low}_{i, t}}\right)
$$

Prior papers demonstrate that the range based volatility estimator appears robust to microstructure noise such as bid-ask bounce (e.g. Brandt and Diebold, 2006). ${ }^{20}$

\subsection{Methodology}

The FX and equity markets can incorporate new information very quickly. Therefore, we employ both $[t+0]$ and $[t+1]$ windows to capture the market reactions following releases of rating news. While $[\mathrm{t}+0]$ measures the return and volatility change from day $t-1$ to day $t,[\mathrm{t}+1]$ reflects the corresponding measures from day $t$ to day $t+1$. [1,5] captures any reactions during the first week following sovereign credit rating events. ${ }^{21} \mathrm{FX}$ rates are often assumed to follow a martingale process (e.g. Andersen et al., 2003a). Therefore, FX returns are employed as abnormal returns. For stock indices, we employ mean-adjusted abnormal returns. ${ }^{22}$ The abnormal return of a stock index on a given day equals its logarithmic return on the day minus the mean return during the period from day -250 to day -50 .

We estimate the following equations:

$$
r_{i, s}=\alpha+\beta * \Delta L C C R_{i, t}+\gamma_{1} * C C R_{i, t-1}+\gamma_{2} * r_{i, t-1}+\gamma_{3} * \text { int }_{i, t-1}+\varsigma^{*} C o+\xi * \text { Year }+u_{i, t}
$$

\footnotetext{
${ }^{20}$ Options on stock indices did not exist for many sampled countries, thus we cannot conduct investigations of stock index option-implied volatility for all cases. A sample of RV based on intraday data of stock indices is retrieved from Oxford-Man Institute of Quantitative Finance. However, this sample covers only 11 of the sampled countries. Most of these have limited numbers of rating events i.e. 38 first-move and 65 additional-move actions. The investigations based on this sample (available on request) yield similar results to those presented in this paper. ${ }^{21}$ Equations (19) and (20) are estimated using [-1] and [-5, -1] time windows. The results, available on request, show that the coefficient of $\triangle \mathrm{LCCR}$ is insignificant in all estimations. This implies that any endogeneity problem is unlikely to be present. In other words, negative sovereign credit rating news seems not to be leaked during our sample period.

${ }^{22}$ We also employ the market model with MSCI World Stock Index as a proxy for the market portfolio. The results (available upon request) are very similar.
} 
$\Delta V_{i, s}=\alpha+\beta^{*}\left|\Delta L C C R_{i, t}\right|+\gamma_{1} * C C R_{i, t-1}+\gamma_{2} * r_{i, t-1}+\gamma_{3} *$ int $_{i, t-1}+\varsigma^{*} C o+\xi * Y e a r+u_{i, t}$

$\mathrm{r}_{i, s}$ is a vector of cumulative abnormal returns on country $i$ 's assets i.e. FX rate against the US\$ and stock index during the time windows $s:[t+0],[t+1],[t+1, t+5]$.

$\Delta \mathrm{V}_{i, s}$ is a vector of changes in the volatility measures (RV, IV, High-low range) of country $i$ 's FX rate or stock index during the time window $s$.

$\Delta \mathrm{LCCR}_{i, t}$ represents changes in the log-transformed credit rating of sovereign $i$ at day $t$. We use $\triangle \mathrm{LCCR}$ for Equation (19) whereas $|\Delta \mathrm{LCCR}|$ is used for Equation (20). With returns, the directional effect of rating actions is very important e.g. one expects negative actions to induce currency depreciation. With volatility, we are investigating whether rating actions affect volatility in either positive or negative directions i.e. it is plausible that a negative rating action could increase or decrease volatility e.g. Beber and Brandt (2006, 2009). Our primary focus is to drill down to first-move versus additional actions, in both cases.

CCR is the comprehensive sovereign credit rating. CCR is included as an explanatory variable to control for macroeconomic news and other fundamentals of the rated sovereigns, along with the inclusion of country and year dummies.

$\mathrm{r}_{\mathrm{i}, \mathrm{t}-1}$ is the return of country $i$ 's assets at day $t-1$ (corresponding to the dependent variables i.e. domestic currency and stock index). This variable is included to control for a possible leverage effect (e.g. Andersen et al, 2003a, b).

int $_{\mathrm{i}, \mathrm{t}-1}$ is the domestic policy interest rate which has impact on the FX rates (e.g. Andersen et al., 2003b). Therefore, we include this variable for the FX investigations only. ${ }^{23}$

Co and Year are full vectors of country and year dummies.

\footnotetext{
${ }^{23}$ Equations (19) and (20) are also estimated with an alternative explanatory variable, which is the interest rate spread between a domestic country $i$ and the U.S., to control for the capital flows based on the interest rate differentials. The results, available on request, are consistent. The coefficient is insignificant in all estimations.
} 
We estimate Equations (19) and (20) for first-move and additional-move sovereign credit rating actions, separately. These estimations are based on country-matched samples. From the full sample, we exclude non-rating-event days within six months around sovereign credit rating announcements for each country. Subsequenly, non-rating-event days are randomly selected. For each country, the number of selected non-rating-event observations equals the number of rating events (column 3 of Table 1). This is done to mitigate market noise since the number of credit rating events on each country is very limited compared to the number of non-event days. We perform Monte Carlo experiments based on 10,000 estimations of each equation (e.g. Gande and Parsley, 2005). Each estimation is based on one independent countrymatched sample. The random reshuffling of non-rating-event days many times mitigates the omitted variables problem.

\section{Empirical results}

\subsection{Impact on FX markets}

\subsubsection{Impact on exchange rates}

Table 4 reports the estimated coefficients of Equation (19). The dependent variable is cumulative FX returns over the time windows, i.e. [0], [1], [1, 5] where day 0 denotes rating event days. The main independent variable is the daily change in the log-transformation of the CCR. It should be noted that 1-unit changes in the CCR are associated with varying effects on the LCCR depending on the starting level of a sovereign credit rating (illustrated in Table 2).

Panel A of Table 4 shows that both first-move and additional-move sovereign credit rating news are influential in the market, implying that both types of rating news are informative. The coefficient of $\triangle \mathrm{LCCR}$ is significantly negative implying that deterioration in a sovereign's creditworthiness leads to currency depreciation. A first-move 1-CCR point downgrade of a AAA/Aaa-rated sovereign triggers a 24-basis-points immediate currency 
depreciation on the announcement day $(24$ basis points $=-[-0.0032] * 0.748$ which is $\Delta$ LCCR for AAA/Aaa-rated issuers (see Table 2)). Meanwhile, the additional-move counterparts trigger a change of 24 basis points on day 1 . The effect of first-move sovereign credit rating news is evident for up to a week whereas the impact of additional-move sovereign credit rating news is immediate and short-lived. This supports the heterogeneous beliefs hypothesis in the sense that it takes time for investors to adjust their beliefs in response to the information from the first messenger, whereas there are immediate and decisive market reactions to a second/third messenger's confirmation action.

There is a possibility that the market may react differently to downgrades versus negative outlook/watch announcements. Therefore, we decompose the impact of rating news into: (i) the effect of downgrades (Panel B of Table 4); (ii) the effect of negative outlook/watch (Panel C of Table 4). ${ }^{24}$ First-move rating downgrades trigger immediate reactions on the announcement day, while first-move negative outlook/watch news has a longer lasting effect on FX returns. Additional-move counterparts only trigger short-lived reactions (day [1]). Because $93 \%$ of the downgrades in the sample were preceded by outlook/watch announcements (see Table 3 and Section 4.1.1), market participants were potentially aware of the negative information underlying the downgrades prior to the event. Therefore, such downgrades might confirm prior anticipation rather than increasing the heterogeneity of investors' beliefs. In that sense, first-move negative outlook/watch signals are more likely to be controversial or unexpected, and thereby induce longer-lasting effects in returns. In contrast, additional-move negative outlook/watch signals do not induce long-lasting effects, which can be explained by considering investors' heterogeneous beliefs.

\footnotetext{
${ }^{24}$ We focus on negative news when decomposing the rating news impact for two reasons: (i) prior literature shows that negative news tends to matter more (e.g. Gande and Parsley, 2005); (ii) there were limited numbers of firstmove upgrades (positive outlook/watch) during the sample period.
} 
The magnitude of the effects on FX returns from first-move rating sovereign credit news is larger than from additional-move sovereign credit news. A 1-notch downgrade of a AAA/Aaa-rated sovereign triggers a 122 (75) basis points depreciation if the downgrade comes from the first (later) messenger for the [0] ([1]) windows. ${ }^{25}$ The coefficients of CCR are insignificant, implying that the current level of creditworthiness is not influential.

This empirical evidence of Table 4 supports $\mathrm{H}_{3}$, rejects $\mathrm{H}_{1}$, and is strongly consistent with the predictions of our model relating to heterogeneous beliefs interacting with multiple sovereign credit ratings.

\subsubsection{Impact on foreign exchange rate volatility}

Tables 5 and 6 report the estimated coefficients of Equation (20) using RV and IV as the proxy for FX volatility, respectively. Specifically, the dependent variable in Table 5 (6) is cumulative changes in RV (IV) over the time windows, i.e. [0], [1], [1, 5] where day 0 denotes rating event days. The main independent variable is the absolute value of the daily change in the rating scale.

Panel A of Table 5 shows that both first-move and additional-move sovereign credit rating news triggers significant movements in $\mathrm{RV}$. This is consistent with the reactions of FX rates (presented in Table 4) indicating that both types of sovereign credit rating news are informative. The reactions to first-move sovereign credit rating news are very different from those for additional-move sovereign credit rating news. In cases of first-move news, the coefficient of $|\triangle \mathrm{LCCR}|$ is significantly positive for the [0] window implying that first-move rating actions trigger volatility. Meanwhile, additional-move rating signals lead to reduced volatility i.e. the coefficient of $|\triangle \mathrm{LCCR}|$ is significantly negative for the [1] window. The effect of both first-move and additional-move rating news on FX volatility is immediate and short-

\footnotetext{
${ }^{25} 121$ basis points $=[-0.0078] *[-1.555] ; 75$ basis points $=[-0.0048] *[-1.555] .1 .555$ is $\Delta$ LCCR for top-rated issuers (see Panel B of Table 4 and Table 2).
} 
lived. The results reject hypothesis $\mathrm{H}_{2}$ in favour of $\mathrm{H}_{4}$ thus presenting important evidence of investors' heterogeneous beliefs. First-move sovereign credit rating news increases disagreements among investors regarding domestic currency whereas reductions in FX market heterogeneity follow additional-move rating news.

The decomposition of the impact of negative sovereign credit rating news (Panels B and $\mathrm{C}$ of Table 5) reveals that both first-move downgrades and negative outlook/watch increase FX realized volatility on the announcement day. In contrast, there is consistent evidence that additional-move downgrades reassure the market i.e. reduced ex-post volatility for the [1] window. The market seems to over-react to additional-move negative outlook/watch signals, whereby RV increases on announcement days and reduces in the following days.

Table 6 reports the estimated coefficients of Equation (20) for IV reactions in response to each type of rating news. Panel A of Table 6 shows that only first-move rating news triggers significant movements in IV on the announcement day. The contrast with Table 5 could be explained by the fact that IV is less sensitive to news compared to RV (see Section 4.1.2 for details). The coefficient of $|\triangle \mathrm{LCCR}|$ is significantly positive implying that first-move rating actions trigger increased IV on the announcement day. The magnitude of the increases in IV is much less than the corresponding effect on RV. For example, Panel B of Table 6 shows that a first-move 1-notch downgrade of a AAA/Aaa-rated sovereign triggers IV increases by $3.81 \%$ $\left(|-1.555|^{*} 0.0245\right)$ on the event days, while the corresponding figure for RV (see Panel B of Table 5) is $29.7 \%\left(|-1.555|^{*} 0.1909\right)$. It is noteworthy that IV captures FX option markets' reactions while RV measures the movements in the underlying FX markets. Option markets tend to play a leading role in the price (information) discovery process (e.g. Chakravarty et al., 2004). Results in Panels B and C of Table 6 show that FX option market participants do not react to additional-move sovereign credit rating news, while first-move sovereign credit downgrades (negative outlook/watch news) trigger significant IV movements for the [0] and 
$[1,5]$ windows (on the announcement day). IV increases on the event days of sovereign rating downgrades, then reduces significantly during the following days, with the magnitude of the reductions being larger than prior increases (see Panel B). Overall, the results in Table 6 reject $\mathrm{H}_{4}$ in favour of $\mathrm{H}_{2}$.

\subsubsection{European countries}

Motivated by the European sovereign debt crisis, we have investigated the research questions using a sub-sample of 22 European countries only. ${ }^{26}$ The results of Equations (19) and (20) as reported in Table 7 are qualitatively similar to those in Tables $4-6 .{ }^{27}$ Panel $\mathrm{A}$ of Table 7 shows that both first-move and additional-move sovereign credit rating downgrades trigger significant movements in exchange rates, implying that both types of rating news are informative. A first-move 1-notch downgrade of a AAA/Aaa-rated EU sovereign triggers a 121basis-point $(-[-0.0078] * 1.555)$ immediate currency depreciation on the announcement day. The additional-move counterparts trigger a change of 76 basis points on day 1 .

Panels B and $\mathrm{C}$ of Table 7 show that both first-move and additional-move sovereign credit rating downgrades have a significant impact on FX volatility. Yet, the reactions to firstmove sovereign credit rating downgrades are very different from those for additional-move rating downgrades. First-move downgrades trigger increases in both realized volatility (Panel B) and implied volatility (Panel C) on the announcement day. In contrast to the results of the full sample (see Section 5.1.2), additional-move downgrades reduce both ex-post and ex-ante volatility in European countries for the [1] and [0] windows respectively. The results are also economically meaningful. A first-move 1-notch downgrade of a AAA/Aaa-rated EU sovereign

\footnotetext{
${ }^{26}$ The sub-sample of European countries includes: Austria, Belgium, Cyprus, Czech Republic, Estonia, Finland, France, Germany, Greece, Hungary, Ireland, Italy, Luxembourg, Malta, Netherlands, Poland, Portugal, Romania, Slovakia, Slovenia, Spain, UK.

27 The cases of 'all rating news' and 'negative outlook/watch signals' are available on request. They are not included in the paper due to space constraints.
} 
triggers a $26.1 \%([0.1678] * 1.555)$ upsurge in FX realized volatility immediately, while an additional-move counterpart reduces realized volatility by $25.3 \%([0.1629] * 1.555)$ for the [1] window. In general, the results for the EU sub-sample support a view that additional-move rating downgrades reduce asset price volatility and uncertainty, with stronger results than for the full sample.

\subsection{Impact on domestic equity markets}

Table 8 reports the estimated coefficients of Equation (19) for stock index abnormal returns. The dependent variable is cumulative abnormal returns over the time windows considered, i.e. [0], [1], [1,5]. Panel A of Table 8 shows that first-move (additional-move) sovereign credit rating news are influential in stock markets on the announcement day (on day 1). The coefficient of $\triangle \mathrm{LCCR}$ is significantly positive suggesting that deterioration in a sovereign's creditworthiness induces falls in its domestic stock index. The decomposition of rating news, presented in Panels $\mathrm{B}$ and $\mathrm{C}$ of Table 8, shows that first-move downgrades have a strong immediate effect. Additional-move rating downgrades and negative outlook/watch news are informative for the [1] window. While negative outlook/watchlist announcements from additional messenger(s) deliver the strongest impact on domestic stock indices, there are insignificant reactions to such news from a first-mover CRA. These results are consistently in support of the heterogeneous beliefs hypothesis.

Table 9 reports the estimated coefficients of Equation (20) for stock indices. The dependent variable is cumulative volatility changes over the time windows considered, i.e. [0], $[1],[1,5]$. The main independent variable is the absolute value of the daily change in the rating scale. Panel A of Table 9 shows that only first-move sovereign credit rating news induces significant increases in equity market volatility for each time window. There is no significant movement in volatility in response to additional-move rating actions. The results reject 
hypothesis $\mathrm{H}_{2}$ and $\mathrm{H}_{4}$. First-move sovereign credit rating news raises the volatility of the rated country's equity market whereas additional rating news has little impact. The decomposition of the impact of sovereign credit rating news is revealed in Panels B and C of Table 9. First-move sovereign rating downgrades induce increased volatility in each time window, while additionalmove downgrades reduce volatility on day 1 . First-move negative outlook/watch news increase volatility for the $[1,5]$ window, while additional-move outlook/watch news have insignificant impact on volatility.

Taken together, the empirical results in Tables 4-8 are in support of: (i) the existence of heterogeneous investors' beliefs in both FX and stock markets; and (ii) additional-move sovereign credit rating news having a coordination role at least in the context of FX markets. In stock markets, only downgrades (not negative outlook/watch announcements) from additional messenger(s) coordinate investors' heterogeneous beliefs.

\subsection{Information content in the downgrades of issuers already on negative outlook/watchlist}

Outlook and watchlist status allow CRAs to "buy time" and signal that the rated sovereign is likely to be downgraded/upgraded in the medium or short term respectively. Outlook/watch signals reveal a significant portion of the negative/positive information underlying any subsequent downgrades/upgrades (e.g. IMF, 2010). Additional-move sovereign credit rating downgrades preceded by outlook/watch announcements confirm both the CRA's own prior opinion and other CRAs' opinions. Under homogeneous beliefs, such downgrades should not contain significant incremental information content, hence should not impose significant impacts on assets' returns nor price volatility. ${ }^{28}$ Specifically, equivalent empirical investigations on downgrades preceded by outlook/watch should reject $\mathrm{H}_{3}$ and $\mathrm{H}_{4}$ in favour of

\footnotetext{
${ }^{28}$ Please note that most downgrades in the sample are one-notch (see Table 3).
} 
$H_{1}$ and $H_{2}$. Table 10 reports the results i.e. estimated coefficients of Equations (19) and (20) based on the sub-sample of sovereign credit rating downgrades preceded by outlook/watch. Panel A shows the results for FX markets while Panel B is for equity markets.

Panel A.1 indicates that first-move (additional-move) sovereign credit announcements of such downgrades trigger reactions in FX and stock index returns for the [0] ([1]) windows, while Panel B.1 shows that first-move downgrades trigger a significant market reaction on the announcement day. Domestic currency depreciation and stock index declines follow such downgrades regardless of whether they are from the first messenger or second/third messengers. This is direct evidence in support of $\mathrm{H}_{3}$. Panels A.2, A.3 and B.2 of Table 10 further confirm the heterogeneous beliefs hypothesis. Additional-move sovereign rating downgrades preceded by outlook/watch announcements induce reductions in both domestic currency volatility and stock index volatility for the [1], [0] and [0] windows respectively. This directly rejects $\mathrm{H}_{2}$ in favour of $\mathrm{H}_{4}$. It is noteworthy that previous results (Table 6, Panel B) suggested that additionalmove sovereign credit rating downgrades do not trigger a significant impact on FX optionimplied volatility. This section suggests the explanation that additional-move downgrades without prior notice (i.e. outlook/watch) induce either no impact or increases in IV.

There is a very small likelihood that sovereign credit rating events may coincide with important macroeconomic news releases within one week after rating events. These macroeconomic fundamentals could drive the movements in domestic stock prices, currency returns and volatilities. Therefore, we conduct robustness checks against business cycle effects. The macroeconomic fundamentals include Gross Domestic Product (GDP), consumer price index (CPI), industrial production index, unemployment rates, fiscal deficit and trade balance for the sampled countries and the U.S. The results (available upon request) are qualitatively similar. We also conduct equivalent investigations on different maturities of the FX optionimplied volatility which yield similar results. 


\section{Conclusions}

During recent crises, CRAs have faced accusations of bias and of lagging financial market movements, hence offering limited informational value. There has been regulatory reform of the rating industry, along with calls for a reduced role of credit ratings in financial markets (e.g. SEC, 2011). This paper seeks to contribute to the debate on the role of the CRA industry and its regulation. In particular, we investigate whether all types of sovereign credit rating news are informative in a context of multiple-rated issuers.

We propose a model where multiple messengers' opinions, i.e. multiple CRAs' sovereign credit rating actions, interact with market heterogeneity. The latter plays a crucial role in solving many financial puzzles (e.g. Li and Muzere, 2010). The model illustrates that the information value of sovereign credit rating news does not lie exclusively in the hands of the first messenger who reveals a new element in the rated issuers' creditworthiness. Additional messengers' confirmation of another CRA's actions could coordinate investors' heterogeneous beliefs. It is noteworthy that our model allows the role of first messenger to switch from one CRA to another over time. The model yields several testable hypotheses regarding financial market reactions, as follows: (i) financial asset prices react to sovereign credit rating news from both types of messengers; (ii) price volatility increases in response to sovereign credit rating news from the first messenger because the news induces uncertainty and disagreement between market participants; (iii) price volatility reduces in response to sovereign credit rating news from additional messenger(s) when they confirm prior news.

Empirical investigations confirm that sovereign credit rating news coordinates investors' beliefs. Based on a comprehensive sample of the largest three CRAs' sovereign credit ratings, we find: (i) both types of rating news have a significant impact on FX and stock index returns with similar magnitude; (ii) FX and stock index volatilities increase in response to sovereign credit rating news from the first messenger, which directly indicates a strong degree 
of heterogeneity in market reactions or investors' beliefs about an item of information; (iii) the volatilities reduce significantly in response to sovereign credit news which contains no new information but rather confirms the prior opinion. A number of robustness checks have been conducted, including an EU sub-sample, Monte Carlo experiments, investigations on a subsample of downgrades of issuers on prior negative outlook/watchlist, and controlling for macroeconomic factors.

In summary, the paper illustrates the importance of sovereign credit rating information from multiple messengers. While the first messenger discloses new information and contributes to the price discovery process, additional messengers play an important role of coordinating investors' heterogeneous beliefs. The findings are, to some extent, consistent with Boot et al. (2006) where ratings act as 'a focal point' and coordinate market actions. However, in contrast to Boot el al. (2006), we show that the coordination role of sovereign credit ratings does not necessarily require a particular CRA to take the leading role in the information discovery process.

Contrary to a popular belief that negative rating actions increase asset price volatility, the paper demonstrates that additional negative sovereign credit rating news does not. The findings raise a caveat against calls for removing credit ratings from investment guidelines and regulations, at least in the context of sovereign credit ratings. There are clearly benefits of reducing overreliance on credit ratings. However, given the fact that a strong degree of market heterogeneity exists, sovereign credit rating signals (especially additional ones) could play an important "confirmation role" and reduce market uncertainty, and therefore could facilitate market access and fund flows. There is also a clear implication for regulators' recent efforts to encourage new entrants to the rating industry. 


\section{References}

Adelino, M., Ferreira, M.A. 2016. Bank ratings and lending supply: Evidence from sovereign downgrades. Review of Financial Studies, 29 (7), 1709-1746.

Afonso, A., Furceri, D., Gomes, P. 2012. Sovereign credit ratings and financial markets linkages: Application to European data. Journal of International Money and Finance 31 (3), 606-638

Almeida, H., Cunha, I., Ferreira, M.A., and Restrepo, F. 2017. The real effects of credit ratings: The sovereign ceiling channel. Journal of Finance 72, 249-290.

Alsakka, R. ap Gwilym, O. 2013. Rating agencies' signals during the European sovereign debt crisis: Market impact and spillovers. Journal of Economic Behavior and Organization 85, $144-162$

An, H., and Chan, K. 2008. Credit ratings and IPO pricing. Journal of Corporate Finance 14, 584-595.

Andersen, T.G., Bollerslev, T., Diebold, F.X., and Labys, P. 2003a. Modelling and forecasting realized volatility. Econometrica 71, 579-625.

Andersen, T.G., Bollerslev, T., Diebold, F.X., and Vega, C. 2003b. Micro effects of macro announcements: Real-time price discovery in foreign exchange. American Economic Review 93, 38-62.

Anderson, E., Ghysels, E., and Juergens, J. 2005. Do heterogeneous beliefs matter for asset pricing? Review of Financial Studies 18, 875-924.

Beber, A., and Brandt, M. 2006. The effect of macroeconomic news on beliefs and preferences: Evidence from the options market. Journal of Monetary Economics 53, 1997-2039.

Beber, A., and Brandt, M. 2009. Resolving macroeconomic uncertainty in stock and bond markets. Review of Finance 13, 1-45.

Bianchi, M., Jehiel, P. 2015. Financial reporting and market efficiency with extrapolative investors. Journal of Economic Theory 157, 842-878.

BIS, 2016. Triennial Central Bank survey of foreign exchange turnover in April 2016. Bank for International Settlements.

Bongaerts, D., Cremers, K. J, and Goetzmann, W.N. 2012. Tiebreaker: Certification and multiple credit ratings. Journal of Finance 67, 113-152.

Boot, A.W., Milbourn, T.T., and Schmeits, A. 2006. Credit ratings as coordination mechanisms. Review of Financial Studies 19, 81-118. 
Brandt, M., and Diebold, F. 2006. A no-arbitrage approach to range-based estimation of return covariances and correlations. Journal of Business 79, 61-74.

Buraschi, A., and Jiltsov, A. 2006. Model uncertainty and option markets with heterogeneous beliefs. Journal of Finance 61, 2841-97.

Cai, P., Kim, S., Wu, E., 2018. Foreign direct investments from emerging markets: The pushpull effects of sovereign credit ratings. International Review of Financial Analysis. Forthcoming.

Chakravarty, S., Gulen, H., and Mayhew, S. 2004. Informed trading in stock and option markets. Journal of Finance 59, 1235-1257.

Chen, J., Hong, H., and Stein, J. 2002. Breadth of ownership and stock returns. Journal of Financial Economics 66, 171-205.

Christensen, B.J., and Prabhala, N.R. 1998. The relation between implied and realized volatility. Journal of Financial Economics, 50, 125-150.

Cornaggia, J.N., Cornaggia, K.J., and Hund, J.E. 2017. Credit ratings across asset classes: A long-term perspective. Review of Finance 21, 465-509.

De Santis, R.A., 2014. The euro area sovereign debt crisis: Identifying flight-to-liquidity and the spillover mechanisms. Journal of Empirical Finance 26, 150-170.

Dittmar, F., and Yuan, K. 2008. Do sovereign bonds benefit corporate bonds in emerging markets? Review of Financial Studies 21, 1983-2014.

Drago, D., Gallo, R. 2016. The impact and the spillover effect of a sovereign rating announcement on the euro area CDS market. Journal of International Money and Finance 67, 264-286.

European Securities and Markets Authority (ESMA) 2016. Competition and choice in the credit rating industry. Market share calculation required by Article 8d of Regulation 1060/2009 on Credit Rating Agencies as amended. December $16^{\text {th }}$, 2016. ESMA/2016/1662.

Fitch Ratings, 2017. Sovereign Rating Criteria. July 2017.

Gande, A., and Parsley, D. C. 2005. News spillovers in the sovereign debt market. Journal of Financial Economics 75, 691-734.

Hill, P., Faff, R. 2010. The market impact of relative agency activity in the sovereign ratings market. Journal of Business Finance and Accounting 37, 1309-1347.

Hill, P, Bissoondoyal-Bheenick, E. Faff, R. 2018. New evidence on sovereign to corporate credit rating spill-overs. International Review of Financial Analysis 55, pp. 209-225

Hong, H., and Stein, J. 2003. Differences of opinion, short-sales constraints, and market crashes. Review of Financial Studies 16, 487-525. 
International Monetary Fund (IMF). 2010. Chapter 3: The uses and abuses of sovereign credit ratings. Global Stability Report.

Ismailescu, I., Kazemi, H. 2010. The reaction of emerging market credit default swap spreads to sovereign credit rating changes. Journal of Banking and Finance 34(12), 2861-2873.

Jory, S.R., Ngo, T.N., and Wang, D. 2016. Credit ratings and the premiums paid in mergers and acquisitions. Journal of Empirical Finance 39, 93 - 104.

Kaminsky, G., Schmukler, S.L. 2002. Emerging markets instability: Do sovereign ratings affect country risk and stock returns? The World Bank Economic Review 16(2), 171-195.

Kim, J., Wu, E. 2011. International bank flows to emerging markets: Influence of sovereign credit ratings and their regional spillover effects. Journal of Financial Research 34, 331-364.

Li, T., and Muzere, M., 2010. Heterogeneity and volatility puzzles in international finance. Journal of Financial and Quantitative Analysis 45, 1485-1516.

Mathis, J., McAndrew, J., and Rochet, J.-C., 2009. Rating the raters: Are reputation concerns powerful enough to discipline rating agencies? Journal of Monetary Economics 56, 657674.

Moody's, 2015. Rating Methodology: Sovereign bond ratings. Research paper.

Parkinson, M., 1980. The extreme value method for estimating the variance of the rate of return. Journal of Business 53, 61-65.

Remolona, E. M., Scatigna, M., Wu, E. 2008. The dynamic pricing of sovereign risk in emerging markets: Fundamentals and risk aversion. Journal of Fixed Income 17, 57-71.

S\&P, 2014. Sovereign government rating methodology and assumptions.

S\&P, 2013. Sovereign defaults and rating transition data, 2012 Update. Ratings Direct.

Securites and Exchange Commission (SEC), 2011. References to credit ratings in certain Investment Company Act rules and forms.

Sy, A. 2004. Rating the rating agencies: Anticipating currency crises or debt crises? Journal of Banking and Finance 28 (11), 2845-2867.

Vu, H., Alsakka, R., ap Gwilym, O. 2017. What drives differences of opinion in sovereign ratings? The roles of political risk and transparency. International Journal of Finance and Economics 22, 216-233.

Xiong, W., and Yan, H. 2010. Heterogeneous expectations and bond markets. Review of Financial Studies 23, 1434-1466. 
Table 1: List of sample countries

\begin{tabular}{|c|c|c|c|c|c|}
\hline & Country & No. of events & & Country & No. of events \\
\hline (1) & (2) & (3) & $(1)$ & (2) & (3) \\
\hline 1 & Australia & 1 & 22 & Luxembourg & 4 \\
\hline 2 & Austria & 4 & 23 & Malaysia $^{\dagger}$ & 4 \\
\hline 3 & Belgium & 11 & 24 & Malta & 6 \\
\hline 4 & Brazil & 14 & 25 & Mexico & 9 \\
\hline 5 & Chile & 9 & 26 & Netherlands & 4 \\
\hline 6 & Colombia & 12 & 27 & New Zealand & 5 \\
\hline 7 & Cyprus & 32 & 28 & Peru & 16 \\
\hline 8 & Czech Republic & 7 & 29 & Philippines & 12 \\
\hline 9 & Estonia & 6 & 30 & Poland & 5 \\
\hline 10 & Finland & 3 & 31 & Portugal & 24 \\
\hline 11 & France & 5 & 32 & Romania & 6 \\
\hline 12 & Germany & 3 & 33 & Russia $^{\dagger}$ & 13 \\
\hline 13 & Greece & 38 & 34 & Slovakia & 5 \\
\hline 14 & Hungary & 22 & 35 & Slovenia & 16 \\
\hline 15 & India & 4 & 36 & South Africa & 14 \\
\hline 16 & Indonesia & 17 & 37 & Spain & 24 \\
\hline 17 & Ireland & 25 & 38 & Taiwan & 3 \\
\hline 18 & Israel & 7 & 39 & Thailand & 6 \\
\hline 19 & Italy & 12 & 40 & Turkey & 16 \\
\hline 20 & Japan & 10 & 41 & UK & 8 \\
\hline 21 & Korea & 10 & & & \\
\hline
\end{tabular}

The data set covers 41 countries during the period from 2007-2013. Among them, 17 EU countries using the Euro are included in the sample according to when they started using the Euro. All the countries are categorised as free floating or floating FX regimes in every IMF de facto classifications since it began in 2006 except for 2 countries marked by $\uparrow$ categorised in "Other managed arrangement" in 2010 and 2012 when these domestic exchange rate arrangements do not meet the criteria for any of the other categories. 
Table 2: Credit rating scale

\begin{tabular}{|c|c|c|c|c|c|c|}
\hline \multicolumn{2}{|c|}{ Pre-event ratings } & \multirow[b]{2}{*}{ CCR } & \multirow{2}{*}{$\begin{array}{l}\text { LCCR } \\
\operatorname{Eq}(18)\end{array}$} & \multicolumn{3}{|c|}{$\Delta \mathrm{LCCR}$} \\
\hline Ratings & $\begin{array}{c}\text { Outlook/watch } \\
\text { status }\end{array}$ & & & $\begin{array}{c}\text { Negative } \\
\text { outlook action }\end{array}$ & $\begin{array}{c}\text { Negative watch } \\
\text { action }\end{array}$ & $\begin{array}{c}\text { 1-notch } \\
\text { downgrade }\end{array}$ \\
\hline$(1)$ & $(2)$ & (3) & (4) & $(5)$ & $(6)$ & $(7)$ \\
\hline \multirow[t]{3}{*}{ AAA } & Stable & 58 & 11.296 & -0.748 & -1.209 & -1.555 \\
\hline & Neg. outlook & 57 & 10.549 & & & -1.089 \\
\hline & Neg. watch & 56 & 10.087 & & & -0.871 \\
\hline \multirow[t]{3}{*}{$\mathrm{AA}+$} & Stable & 55 & 9.742 & -0.282 & -0.526 & -0.743 \\
\hline & Neg. outlook & 54 & 9.459 & & & -0.659 \\
\hline & Neg. watch & 53 & 9.216 & & & -0.600 \\
\hline \multirow[t]{3}{*}{$\mathrm{AA}$} & Stable & 52 & 8.999 & -0.198 & -0.383 & -0.558 \\
\hline & Neg. outlook & 51 & 8.801 & & & -0.527 \\
\hline & Neg. watch & 50 & 8.616 & & & -0.504 \\
\hline \multirow[t]{3}{*}{ AA- } & Stable & 49 & 8.441 & -0.167 & -0.329 & -0.487 \\
\hline & Neg. outlook & 48 & 8.274 & & & -0.475 \\
\hline & Neg. watch & 47 & 8.112 & & & -0.467 \\
\hline \multirow[t]{3}{*}{$\mathrm{BBB}+$} & Stable & 37 & 6.505 & -0.190 & -0.394 & -0.617 \\
\hline & Neg. outlook & 36 & 6.315 & & & -0.678 \\
\hline & Neg. watch & 35 & 6.111 & & & -0.764 \\
\hline \multirow[t]{3}{*}{ BBB } & Stable & 34 & 5.888 & -0.250 & -0.541 & -0.894 \\
\hline & Neg. outlook & 33 & 5.638 & & & -1.115 \\
\hline & Neg. watch & 32 & 5.347 & & & -1.583 \\
\hline \multirow[t]{3}{*}{ BBB- } & Stable & 31 & 4.994 & -0.471 & -1.229 & -1.661 \\
\hline & Neg. outlook & 30 & 4.523 & & & -1.920 \\
\hline & Neg. watch & 29 & 3.765 & & & -1.605 \\
\hline \multirow[t]{3}{*}{$\mathrm{BB}+$} & Stable & 28 & 3.332 & -0.730 & -1.173 & -1.500 \\
\hline & Neg. outlook & 27 & 2.603 & & & -1.034 \\
\hline & Neg. watch & 26 & 2.159 & & & -0.816 \\
\hline \multirow[t]{3}{*}{$\mathrm{BB}$} & Stable & 25 & 1.833 & -0.264 & -0.489 & -0.687 \\
\hline & Neg. outlook & 24 & 1.569 & & & -0.604 \\
\hline & Neg. watch & 23 & 1.344 & & & -0.545 \\
\hline \multirow[t]{3}{*}{ BB- } & Stable & 22 & 1.145 & -0.180 & -0.347 & -0.503 \\
\hline & Neg. outlook & 21 & 0.965 & & & -0.473 \\
\hline & Neg. watch & 20 & 0.799 & & & -0.450 \\
\hline \multirow[t]{3}{*}{$\mathrm{CCC}+$} & Stable & 10 & -0.642 & -0.157 & -0.323 & -0.503 \\
\hline & Neg. outlook & 9 & -0.799 & & & -0.545 \\
\hline & Neg. watch & 8 & -0.965 & & & -0.604 \\
\hline \multirow[t]{3}{*}{$\mathrm{CCC}$} & Stable & 7 & -1.145 & -0.199 & -0.423 & -0.687 \\
\hline & Neg. outlook & 6 & -1.344 & & & -0.816 \\
\hline & Neg. watch & 5 & -1.569 & & & -1.034 \\
\hline \multirow[t]{3}{*}{ CCC- } & Stable & 4 & -1.833 & -0.327 & -0.770 & -1.500 \\
\hline & Neg. outlook & 3 & -2.159 & & & \\
\hline & Neg. watch & 2 & -2.603 & & & \\
\hline $\mathrm{CC} / \mathrm{D}$ & & 1 & -3.332 & & & \\
\hline
\end{tabular}

This table presents the transformation of ratings to CCR, LCCR numerical scores and how the effect of a given rating action varies across the levels of creditworthiness. Columns (1) and (2) report the starting points of a rated issuer's. The intermediate rating categories (A+/A/A- and $\mathrm{B}+\mathrm{B} / \mathrm{B}-)$ are omitted in the interest of brevity. For ease of presentation, column (1) only specifies rating symbols from $\mathrm{S} \& \mathrm{P}$ and Fitch, but should be considered as including equivalent ratings from Moody's (Aaa, Aa1, Aa2 ... Ca/D). Column (3) shows how the rating symbols along with outlook/watch statuses can be converted to a 58point CCR scale. Column (4) reports a logit-transformation (to address possible rating scale nonlinearity) of the 58-point CCR using Equation (18). Columns (5) - (7) illustrate how the effects of the same rating actions vary depending on the current level of creditworthiness. This table only reflects negative signals (for sake of brevity). A similar scaling can apply for positive rating actions. 
Table 3: Rating events

\begin{tabular}{|c|c|c|c|c|c|c|c|c|c|c|c|c|}
\hline \multirow{3}{*}{ No. of events } & \multicolumn{3}{|c|}{ S\&P } & \multicolumn{3}{|c|}{ Moody's } & \multicolumn{3}{|c|}{ Fitch } & \multicolumn{3}{|c|}{ Total } \\
\hline & up & down & $\Sigma$ & up & Down & $\Sigma$ & up & down & $\Sigma$ & up & down & $\Sigma$ \\
\hline & $(1)$ & (2) & (3) & $(4)$ & $(5)$ & (6) & (7) & (8) & (9) & $(10)$ & $(11)$ & $(12)$ \\
\hline Upgrade/ downgrade & 27 & 56 & 83 & 28 & 48 & 76 & 25 & 45 & 70 & 80 & 149 & 229 \\
\hline Of which: & & & & & & & & & & & & \\
\hline 1-notch up-/downgrade & 23 & 39 & 62 & 28 & 24 & 52 & 23 & 25 & 48 & 74 & 88 & 162 \\
\hline (percentage) & $85 \%$ & $70 \%$ & $75 \%$ & $100 \%$ & $50 \%$ & $68 \%$ & $92 \%$ & $56 \%$ & $69 \%$ & $93 \%$ & $59 \%$ & $71 \%$ \\
\hline Preceded by outlook/watch & 19 & 56 & 75 & 25 & 43 & 68 & 13 & 39 & 52 & 57 & 138 & 195 \\
\hline (percentage) & $70 \%$ & $100 \%$ & $90 \%$ & $89 \%$ & $90 \%$ & $90 \%$ & $52 \%$ & $87 \%$ & $74 \%$ & $71 \%$ & $93 \%$ & $85 \%$ \\
\hline Outlook & 38 & 47 & 85 & 19 & 36 & 55 & 28 & 38 & 66 & 85 & 121 & 206 \\
\hline Watch & 7 & 27 & 34 & 12 & 23 & 35 & 3 & 14 & 17 & 22 & 64 & 86 \\
\hline Total & 72 & 130 & 202 & 59 & 107 & 166 & 56 & 97 & 153 & 187 & 334 & 521 \\
\hline $\begin{array}{l}\text { Total after excluding } \\
\text { events on same } \\
\text { sovereign(s) on same days } \\
\text { Of which: }\end{array}$ & 70 & 113 & 183 & 56 & 82 & 138 & 55 & 83 & 138 & 181 & 278 & 459 \\
\hline - First-move & 16 & 74 & 90 & 14 & 26 & 40 & 23 & 21 & 44 & $\begin{array}{r}53 \\
20 \%\end{array}$ & 121 & 174 \\
\hline & $23 \%$ & $65 \%$ & $49 \%$ & $25 \%$ & $32 \%$ & $29 \%$ & $42 \%$ & $25 \%$ & $32 \%$ & $29 \%$ & $44 \%$ & $38 \%$ \\
\hline - Additional-move & $\begin{array}{r}54 \\
77 \%\end{array}$ & $\begin{array}{r}39 \\
35 \%\end{array}$ & $\begin{array}{r}93 \\
51 \%\end{array}$ & $\begin{array}{r}42 \\
75 \%\end{array}$ & $\begin{array}{r}56 \\
68 \%\end{array}$ & $\begin{array}{r}98 \\
71 \%\end{array}$ & $\begin{array}{r}32 \\
58 \%\end{array}$ & $\begin{array}{r}62 \\
75 \%\end{array}$ & $\begin{array}{r}94 \\
68 \%\end{array}$ & $\begin{array}{l}128 \\
71 \%\end{array}$ & $\begin{array}{l}157 \\
56 \%\end{array}$ & $\begin{array}{l}285 \\
62 \%\end{array}$ \\
\hline
\end{tabular}

This table reports the numbers of rating events released by the CRAs on the sampled countries during the period from January 2007 to April 2013. Columns (1) - (3) report numbers of positive, negative, and total rating signals from S\&P, respectively. Similarly, columns (4) to (9) report corresponding numbers from Moody's and Fitch. Column $(10)=(1)+(4)+(7) ;(11)=(2)+(5)+(8) ;(12)=(3)+(6)+(9)$. During the sample period, the CRAs released 59 combined rating signals and 9 multiple-rating-events days when multiple CRAs announced actions on the same sovereign(s). In these cases, only one action is counted.

Please see Section 4 for more details. 
Table 4: Impact on foreign exchange rates

First-move

\begin{tabular}{|c|c|c|c|}
\hline & [0] & [1] & {$[1,5]$} \\
\hline Panel A & \multicolumn{3}{|c|}{ All rating news } \\
\hline$\triangle \mathrm{LCCR}$ & $-0.0032 *$ & -0.0012 & $-0.0060 * *$ \\
\hline $\mathrm{t}-\mathrm{val}$. & -1.876 & -0.767 & -1.976 \\
\hline CCR & 0.00008 & 0.00010 & 0.00015 \\
\hline $\mathrm{t}$-val. & 1.505 & 1.681 & 1.511 \\
\hline $\mathrm{R}^{2}$ & $8.54 \%$ & $8.16 \%$ & $9.29 \%$ \\
\hline Obs. & 633 & 633 & 633 \\
\hline Panel B & \multicolumn{3}{|c|}{ Downgrades } \\
\hline$\triangle \mathrm{LCCR}$ & $-0.0078 * *$ & 0.0001 & 0.0048 \\
\hline t-val. & -2.184 & 0.042 & 0.804 \\
\hline CCR & 0.00012 & 0.00006 & -0.00002 \\
\hline t-val. & 1.848 & 0.786 & -0.177 \\
\hline $\mathrm{R}^{2}$ & $12.14 \%$ & $9.38 \%$ & $11.15 \%$ \\
\hline Obs. & 522 & 522 & 522 \\
\hline Panel C & \multicolumn{3}{|c|}{ Negative outlook/watch } \\
\hline$\triangle \mathrm{LCCR}$ & -0.0028 & $-0.0047 * * *$ & $-0.0100 * *$ \\
\hline t-val. & -1.138 & -2.592 & -2.372 \\
\hline CCR & 0.00006 & 0.00013 & 0.00018 \\
\hline t-val. & 0.837 & 1.920 & 1.379 \\
\hline $\mathrm{R}^{2}$ & $9.15 \%$ & $12.24 \%$ & $12.42 \%$ \\
\hline Obs. & 526 & 526 & 526 \\
\hline
\end{tabular}

Additional-move

\begin{tabular}{|rrr|}
\multicolumn{1}{c}{$[0]$} & \multicolumn{1}{c}{$[1]$} \\
\hline \multicolumn{3}{c}{ All rating news } \\
\hline-0.0006 & $-0.0032^{* *}$ & 0.0003 \\
-0.417 & -2.098 & 0.065 \\
0.00001 & 0.00000 & -0.00004 \\
0.159 & -0.053 & -0.470 \\
$7.59 \%$ & $8.50 \%$ & $8.40 \%$ \\
744 & 744 & 744 \\
\hline \multicolumn{3}{|c}{ Downgrades } \\
\hline-0.0002 & $-0.0048 *$ & -0.0047 \\
-0.087 & -1.776 & -0.724 \\
-0.00002 & 0.00003 & 0.00006 \\
-0.383 & 0.430 & 0.437 \\
$9.40 \%$ & $11.19 \%$ & $11.53 \%$ \\
528 & 528 & 528 \\
\hline Negative outlook/watch \\
\hline-0.0026 & $-0.0059 * * *$ & -0.0076 \\
-1.497 & -3.572 & -1.123 \\
0.00001 & -0.00002 & 0.00011 \\
0.227 & -0.447 & 0.773 \\
$9.79 \%$ & $10.61 \%$ & $10.32 \%$ \\
556 & 556 & 556 \\
\hline \multicolumn{3}{c}{}
\end{tabular}

This table reports the average values from 10,000 estimations of Equation (19) with Huber-White robust standard errors. The dependent variable is cumulative FX returns over the time windows. The main independent variable is $\triangle \mathrm{LCCR}$, daily changes in the log-transformation of ratings. Control variables include rating level (CCR); and lagged FX returns and policy interest rates, country and year dummies which are not reported to conserve space. Monte Carlo resampling is used. Each sample is countrymatched i.e. numbers of non-event observations in each country equal corresponding numbers in column 3 of Table $1 . *, * *, * * *$ denote significance at the $10 \%, 5 \%, 1 \%$ levels. 
Table 5: Impact on foreign exchange realized volatility

First-move

\begin{tabular}{|c|c|c|c|}
\hline & [0] & [1] & {$[1,5]$} \\
\hline Panel A & \multicolumn{3}{|c|}{ All rating news } \\
\hline$|\Delta \mathrm{LCCR}|$ & $0.1706^{* * *}$ & -0.1050 & -0.1186 \\
\hline t-val. & 2.648 & -1.420 & -1.269 \\
\hline CCR & 0.00020 & -0.00361 & 0.00399 \\
\hline t-val. & 0.059 & -1.078 & 1.000 \\
\hline $\mathrm{R}^{2}$ & $9.39 \%$ & $10.17 \%$ & $9.55 \%$ \\
\hline Obs. & 560 & 560 & 560 \\
\hline Panel B & \multicolumn{3}{|c|}{ Downgrades } \\
\hline$|\Delta \mathrm{LCCR}|$ & $0.1909 * *$ & -0.2113 & 0.0102 \\
\hline t-val. & 1.997 & -1.626 & 0.078 \\
\hline CCR & 0.00072 & -0.00259 & 0.00101 \\
\hline t-val. & 0.167 & -0.631 & 0.205 \\
\hline $\mathrm{R}^{2}$ & $11.30 \%$ & $11.32 \%$ & $11.09 \%$ \\
\hline Obs. & 474 & 474 & 474 \\
\hline Panel C & \multicolumn{3}{|c|}{ Negative outlook/watch } \\
\hline$|\Delta \mathrm{LCCR}|$ & $0.1171^{*}$ & -0.1407 & 0.0528 \\
\hline t-val. & 1.693 & -1.592 & 0.689 \\
\hline CCR & -0.00148 & -0.00044 & 0.00040 \\
\hline t-val. & -0.359 & -0.104 & 0.088 \\
\hline $\mathrm{R}^{2}$ & $10.87 \%$ & $11.53 \%$ & $11.41 \%$ \\
\hline Obs. & 480 & 480 & 480 \\
\hline
\end{tabular}

Additional-move

$[0]$

\begin{tabular}{|rrr|}
\hline \multicolumn{3}{|c|}{ All rating news } \\
\hline 0.1998 & $-0.1084 *$ & 0.0378 \\
1.550 & -1.791 & 0.354 \\
0.00549 & -0.00183 & 0.00457 \\
1.576 & -0.587 & 1.265 \\
$7.25 \%$ & $9.93 \%$ & $9.15 \%$ \\
662 & 662 & 662 \\
\hline \multicolumn{3}{|c|}{ Downgrades } \\
\hline 0.1145 & $-0.175 *^{*} *$ & 0.2048 \\
1.227 & -2.275 & 1.619 \\
0.00549 & -0.00425 & 0.00427 \\
1.429 & -1.090 & 0.962 \\
$10.98 \%$ & $11.33 \%$ & $10.51 \%$ \\
430 & 480 & 480 \\
\hline Negative outlook/watch \\
\hline $0.2589 * * *$ & $-0.0903 *$ & 0.1420 \\
2.643 & -1.722 & 0.840 \\
0.00545 & -0.00215 & 0.00623 \\
1.283 & -0.527 & 1.348 \\
$10.42 \%$ & $10.69 \%$ & $10.11 \%$ \\
508 & 508 & 508 \\
\hline \multicolumn{3}{|c}{}
\end{tabular}

This table reports the average values from 10,000 estimations of Equation (20) with Huber-White robust standard errors. The dependent variable is cumulative changes in FX Realized volatility over the time windows. The main independent variable is $|\Delta \mathrm{LCCR}|$, absolute values of daily changes in the logtransformation of ratings. Control variables include rating level (CCR); and lagged FX returns and policy interest rates, country and year dummies which are not reported to conserve space. Monte Carlo resampling is used. Each sample is country-matched i.e. numbers of non-event observations in each country equal corresponding numbers in column 3 of Table $1 . *, * *, * * *$ denote significance at the $10 \%$, $5 \%, 1 \%$ levels. 
Table 6: Impact on foreign exchange uncertainty (option-implied volatility)

First-move

\begin{tabular}{|c|c|c|c|}
\hline & [0] & [1] & {$[1,5]$} \\
\hline Panel A & \multicolumn{3}{|c|}{ All rating news } \\
\hline$|\triangle \mathrm{LCCR}|$ & $0.0210 * *$ & 0.0089 & -0.0258 \\
\hline t-val. & 2.114 & 1.120 & -1.475 \\
\hline CCR & $0.00074 *$ & -0.00026 & -0.00094 \\
\hline $\mathrm{t}$-val. & 1.692 & -0.592 & -1.219 \\
\hline $\mathrm{R}^{2}$ & $8.48 \%$ & $8.81 \%$ & $9.83 \%$ \\
\hline Obs. & 633 & 633 & 633 \\
\hline Panel B & \multicolumn{3}{|c|}{ Downgrades } \\
\hline$|\Delta \mathrm{LCCR}|$ & $0.0245^{*}$ & -0.0014 & $-0.0655^{* *}$ \\
\hline t-val. & 1.671 & -0.122 & -2.391 \\
\hline CCR & 0.00049 & -0.00038 & -0.00149 \\
\hline t-val. & 0.874 & -0.595 & -1.550 \\
\hline $\mathrm{R}^{2}$ & $12.35 \%$ & $10.79 \%$ & $12.88 \%$ \\
\hline Obs. & 522 & 522 & 522 \\
\hline Panel C & \multicolumn{3}{|c|}{ Negative outlook/watch } \\
\hline$|\Delta \mathrm{LCCR}|$ & $0.0181 *$ & 0.0051 & -0.0167 \\
\hline t-val. & 1.873 & 0.541 & -0.756 \\
\hline CCR & 0.00019 & -0.00015 & -0.00053 \\
\hline t-val. & 0.356 & -0.230 & -0.537 \\
\hline $\mathrm{R}^{2}$ & $11.21 \%$ & $10.49 \%$ & $11.63 \%$ \\
\hline Obs. & 526 & 526 & 526 \\
\hline
\end{tabular}

Additional-move

[0] [1] [1,5]

\begin{tabular}{|rcr|}
\hline \multicolumn{3}{|c|}{ All rating news } \\
\hline 0.0104 & -0.0013 & 0.0146 \\
0.764 & -0.107 & 0.737 \\
0.00024 & -0.00028 & 0.00001 \\
0.532 & -0.675 & 0.034 \\
$7.64 \%$ & $6.50 \%$ & $7.91 \%$ \\
744 & 744 & 744 \\
\hline \multicolumn{3}{|c}{ Downgrades } \\
\hline-0.0178 & 0.0115 & 0.0108 \\
-1.595 & 1.258 & 0.365 \\
-0.00016 & -0.00027 & 0.00007 \\
-0.274 & -0.485 & 0.094 \\
$11.36 \%$ & $11.62 \%$ & $11.72 \%$ \\
528 & 528 & 528 \\
\hline Negative outlook/watch \\
\hline 0.0008 & 0.0216 & 0.0097 \\
0.101 & 1.392 & 0.273 \\
0.00034 & -0.00004 & 0.00064 \\
0.654 & -0.059 & 0.776 \\
$10.28 \%$ & $10.57 \%$ & $10.86 \%$ \\
556 & 556 & 556 \\
\hline \multicolumn{3}{|c}{}
\end{tabular}

This table reports the average values from 10,000 estimations of Equation (20) with Huber-White robust standard errors. The dependent variable is cumulative changes in FX option-implied volatility over the time windows. The main independent variable is $|\triangle \mathrm{LCCR}|$, absolute values of daily changes in the logtransformation of ratings. Control variables include rating level (CCR); and lagged FX returns and policy interest rates, country and year dummies which are not reported to conserve space. Monte Carlo resampling is used. Each sample is country-matched i.e. numbers of non-event observations in each country equal corresponding numbers in column 3 of Table $1 . * * *, * * *$ denote significance at the $10 \%$, $5 \%, 1 \%$ levels. 
Table 7: Impact of EU sovereign rating downgrades

First-move

[0]

[1]

$[1,5]$

[0]

Additional-move

[1]

$[1,5]$

\begin{tabular}{|c|c|c|c|c|c|c|}
\hline \multicolumn{7}{|c|}{ Panel A: Impact on exchange rates } \\
\hline$\triangle \mathrm{LCCR}$ & $-0.0078^{* *}$ & 0.0015 & 0.0048 & -0.0003 & $-0.0049^{*}$ & -0.0063 \\
\hline $\mathrm{t}$-val. & -2.077 & 0.577 & 0.810 & -0.123 & -1.773 & -0.956 \\
\hline CCR & 0.0001 & 0.0000 & -0.0001 & 0.0000 & 0.0000 & -0.0001 \\
\hline t-val. & 1.578 & 0.501 & -0.342 & -0.579 & 0.130 & -0.458 \\
\hline Interest & 0.0019 & 0.0008 & -0.0008 & 0.0003 & 0.0000 & 0.0017 \\
\hline t-val. & 1.556 & 0.574 & -0.294 & 0.178 & -0.070 & 0.701 \\
\hline $\mathrm{R}^{2}$ & $14.55 \%$ & $8.92 \%$ & $11.48 \%$ & $9.11 \%$ & $12.76 \%$ & $11.92 \%$ \\
\hline Obs. & 332 & 332 & 332 & 340 & 340 & 340 \\
\hline
\end{tabular}

Panel B: Impact on FX realized volatility

\begin{tabular}{|c|c|c|c|c|c|c|}
\hline$|\Delta \mathrm{LCCR}|$ & $0.1678^{*}$ & -0.1610 & -0.0241 & 0.0797 & $-0.1629^{* * *}$ & 0.2634 \\
\hline t-val. & 1.664 & -1.264 & -0.1864 & 0.920 & -2.437 & 1.536 \\
\hline CCR & 0.0030 & -0.0059 & 0.0016 & 0.0055 & -0.0063 & 0.0056 \\
\hline t-val. & 0.718 & -1.454 & 0.305 & 1.597 & -1.775 & 1.253 \\
\hline Interest & 0.0448 & -0.0224 & 0.0654 & -0.0212 & -0.0007 & 0.0018 \\
\hline t-val. & 0.570 & -0.333 & 0.730 & -0.229 & -0.076 & 0.008 \\
\hline $\mathrm{R}^{2}$ & $11.01 \%$ & $11.69 \%$ & $10.60 \%$ & $10.57 \%$ & $11.98 \%$ & $11.35 \%$ \\
\hline Obs. & 298 & 298 & 298 & 305 & 305 & 305 \\
\hline \multicolumn{7}{|c|}{ Panel C: Impact on FX option-implied volatility } \\
\hline$|\Delta \mathrm{LCCR}|$ & $0.0580^{* * * *}$ & -0.0035 & -0.0896 & $-0.0279^{*}$ & 0.0242 & 0.0241 \\
\hline t-val. & 2.625 & -0.243 & -1.471 & -1.847 & 1.057 & 0.599 \\
\hline CCR & 0.0006 & -0.0002 & -0.0024 & -0.001 & -0.001 & -0.001 \\
\hline t-val. & 1.100 & -0.415 & -2.336 & -0.763 & -0.260 & -0.803 \\
\hline Interest & 0.0086 & -0.0044 & -0.0160 & -0.0054 & -0.0026 & -0.0139 \\
\hline t-val. & 1.347 & -0.620 & -0.877 & -0.887 & -0.363 & -0.803 \\
\hline $\mathrm{R}^{2}$ & $12.97 \%$ & $10.63 \%$ & $10.01 \%$ & $12.49 \%$ & $11.33 \%$ & $10.03 \%$ \\
\hline Obs. & 332 & 332 & 332 & 340 & 340 & 340 \\
\hline
\end{tabular}

This table reports the average values from 10,000 estimations of Equations (19) and (20) with Huber-White robust standard errors based on the EU sub-sample. The dependent variables are cumulative FX returns (in Panel A), cumulative changes in FX Realized Volatility (in Panel B) and FX Option-Implied Volatility (in Panel C) over the time windows. The main independent variable is $\triangle \mathrm{LCCR}$ in Panel A and $|\triangle \mathrm{LCCR}|$ in Panels B and C. Control variables include rating level (CCR); and lagged FX returns and policy interest rates, interest spread between the domestic country and U.S, country and year dummies which are not reported to conserve space. Monte Carlo resampling is used. Each sample is country-matched i.e. numbers of non-event observations in each country equal corresponding numbers in column 3 of Table $1 . *, * * * *$ denote significance at the $10 \%, 5 \%, 1 \%$ levels. 
Table 8: Impact on domestic stock indices' mean-adjusted abnormal returns

First-move

\begin{tabular}{|c|c|c|c|}
\hline \multirow[b]{2}{*}{ Panel A } & [0] & [1] & {$[1,5]$} \\
\hline & \multicolumn{3}{|c|}{ All rating news } \\
\hline$\triangle \mathrm{LCCR}$ & $0.0043^{*}$ & 0.0013 & 0.0004 \\
\hline t-val. & 1.803 & 0.217 & 0.036 \\
\hline CCR & -0.0001 & -0.0002 & -0.0008 \\
\hline t-val. & -0.948 & -1.220 & -1.949 \\
\hline $\mathrm{R}^{2}$ & $6.97 \%$ & $8.16 \%$ & $10.95 \%$ \\
\hline Obs. & 633 & 633 & 633 \\
\hline Panel B & \multicolumn{3}{|c|}{ Downgrades } \\
\hline$\Delta \mathrm{LCCR}$ & $0.0133^{*}$ & -0.0200 & -0.0660 \\
\hline t-val. & 1.811 & -1.545 & -1.394 \\
\hline CCR & -0.0002 & 0.0001 & 0.0005 \\
\hline t-val. & -1.007 & 0.564 & 1.157 \\
\hline $\mathrm{R}^{2}$ & $8.74 \%$ & $9.96 \%$ & $17.67 \%$ \\
\hline Obs. & 522 & 522 & 522 \\
\hline Panel C & \multicolumn{3}{|c|}{ Negative outlook/watch } \\
\hline$\triangle \mathrm{LCCR}$ & 0.0018 & 0.0019 & 0.0012 \\
\hline t-val. & 0.349 & 0.188 & 0.067 \\
\hline CCR & 0.0000 & -0.0004 & -0.0009 \\
\hline t-val. & -0.134 & -1.351 & -1.812 \\
\hline $\mathrm{R}^{2}$ & $8.08 \%$ & $9.12 \%$ & $12.52 \%$ \\
\hline Obs. & 526 & 526 & 526 \\
\hline
\end{tabular}

Additional-move

\begin{tabular}{|rcr|}
\multicolumn{4}{|c}{$[0]$} & \multicolumn{1}{c}{$[1]$} & \multicolumn{1}{c|}{$[1,5]$} \\
\hline 3 & All rating news \\
0.0007 & $0.0061^{* *}$ & -0.0041 \\
0.149 & 2.040 & -0.443 \\
0.0001 & -0.0001 & -0.0001 \\
0.474 & -1.305 & -0.389 \\
$6.04 \%$ & $6.15 \%$ & $10.25 \%$ \\
744 & 744 & 744 \\
\hline \multicolumn{3}{|c}{ Downgrades } \\
\hline 0.0060 & $0.0091^{*}$ & 0.0017 \\
0.569 & 1.953 & 0.122 \\
0.0001 & -0.0002 & -0.0004 \\
0.359 & -1.206 & -0.801 \\
$8.13 \%$ & $9.81 \%$ & $14.37 \%$ \\
528 & 528 & 528 \\
\hline Negative outlook/watch \\
\hline 0.0115 & $0.0116^{* * *}$ & 0.0166 \\
1.208 & 2.809 & 1.197 \\
-0.0003 & -0.0001 & -0.0006 \\
-1.506 & -0.619 & -1.468 \\
$7.85 \%$ & $7.88 \%$ & $13.04 \%$ \\
556 & 556 & 556 \\
\hline \multicolumn{3}{c}{}
\end{tabular}

This table reports the average values from 10,000 estimations of Equation (19) with Huber-White robust standard errors. The dependent variable is cumulative abnormal returns over the time windows. An abnormal return equals the return on an announcement day less the average return during the pre-even period of $[-250,-50]$. The main independent variable is $\Delta \mathrm{LCCR}$, daily changes in the log-transformation of ratings. Control variables include rating level (CCR); and lagged abnormal returns, country and year dummies which are not reported to conserve space. Monte Carlo resampling is used. Each sample is country-matched i.e. numbers of non-event observations in each country equal corresponding numbers in column 3 of Table $1 . *, * *, * * *$ denote significance at the $10 \%, 5 \%, 1 \%$ levels. 
Table 9: Impact on stock indices' volatility

First-move

\begin{tabular}{|c|c|c|c|}
\hline & [0] & [1] & {$[1,5]$} \\
\hline Panel A & \multicolumn{3}{|c|}{ All rating news } \\
\hline$|\Delta \mathrm{LCCR}|$ & $0.0069^{* *}$ & $0.0060^{*}$ & $0.0362^{* * *}$ \\
\hline t-val. & 2.316 & 1.835 & 2.586 \\
\hline CCR & 0.0002 & 0.0001 & 0.0008 \\
\hline t-val. & 1.620 & 0.693 & 1.525 \\
\hline $\mathrm{R}^{2}$ & $22.24 \%$ & $21.35 \%$ & $25.57 \%$ \\
\hline Obs. & 633 & 633 & 633 \\
\hline Panel B & \multicolumn{3}{|c|}{ Downgrades } \\
\hline$|\Delta \mathrm{LCCR}|$ & $0.0124^{*}$ & $0.0157^{* * *}$ & $0.0584^{* * *}$ \\
\hline t-val. & 1.778 & 3.017 & 2.894 \\
\hline CCR & 0.0002 & 0.0002 & 0.0010 \\
\hline t-val. & 1.248 & 1.092 & 1.521 \\
\hline $\mathrm{R}^{2}$ & $26.18 \%$ & $27.83 \%$ & $31.30 \%$ \\
\hline Obs. & 522 & 522 & 522 \\
\hline Panel C & \multicolumn{3}{|c|}{ Negative outlook/watch } \\
\hline$|\Delta \mathrm{LCCR}|$ & 0.0009 & 0.0052 & $0.0401^{* *}$ \\
\hline t-val. & 0.278 & 1.172 & 2.066 \\
\hline CCR & 0.0001 & 0.0000 & 0.0004 \\
\hline t-val. & 1.025 & -0.062 & 0.475 \\
\hline $\mathrm{R}^{2}$ & $20.90 \%$ & $20.05 \%$ & $30.37 \%$ \\
\hline Obs. & 526 & 526 & 526 \\
\hline
\end{tabular}

Additional-move

\begin{tabular}{|rrr|}
\multicolumn{1}{c}{$[0]$} & \multicolumn{1}{c}{$[1]$} & \multicolumn{1}{c|}{$[1,5]$} \\
\hline \multicolumn{3}{|c|}{ All rating news } \\
\hline 0.0053 & 0.0032 & 0.0171 \\
1.624 & 1.439 & 1.446 \\
0.0002 & 0.0002 & 0.0008 \\
1.591 & 2.195 & 1.623 \\
$12.85 \%$ & $12.45 \%$ & $12.09 \%$ \\
744 & 744 & 744 \\
\hline \multicolumn{3}{|c}{ Downgrades } \\
\hline 0.0063 & $-0.0053^{*}$ & -0.0276 \\
1.508 & -1.893 & -1.270 \\
0.0002 & 0.0002 & 0.0010 \\
1.311 & 1.287 & 1.341 \\
$22.13 \%$ & $30.56 \%$ & $22.07 \%$ \\
528 & 528 & 528 \\
\hline Negative outlook/watch \\
\hline 0.0104 & 0.0061 & 0.0460 \\
1.487 & 1.445 & 1.437 \\
0.0001 & 0.0002 & 0.0008 \\
0.687 & 1.595 & 1.217 \\
$14.21 \%$ & $13.16 \%$ & $13.91 \%$ \\
556 & 556 & 556 \\
\hline \multicolumn{3}{c}{}
\end{tabular}

This table reports the average values from 10,000 estimations of Equation (20) with Huber-White robust standard errors. The dependent variable is cumulative changes in intraday high-low range over the time windows. The main independent variable is $|\triangle \mathrm{LCCR}|$, absolute values of daily changes in the logtransformation of ratings. Control variables include rating level (CCR); and lagged abnormal returns, country and year dummies which are not reported to conserve space. Monte Carlo resampling is used. Each sample is country-matched i.e. numbers of non-event observations in each country equal corresponding numbers in column 3 of Table 1. *, **, *** denote significance at the $10 \%, 5 \%, 1 \%$ levels. 
Table 10: Impact of downgrades with prior negative outlook/watch

[0]

[1]

$[1,5]$

[0]

[1]

$[1,5]$

\section{Panel A: Impact on FX markets}

A.1: Impact on FX returns

\begin{tabular}{|c|c|c|c|c|c|c|}
\hline & \multicolumn{3}{|c|}{ First-move } & \multicolumn{3}{|c|}{ Additional-move } \\
\hline$\triangle \mathrm{LCCR}$ & $-0.0078^{* *}$ & 0.0002 & 0.0051 & 0.0001 & $-0.0053^{*}$ & -0.0054 \\
\hline t-val. & -2.179 & 0.074 & 0.850 & 0.066 & -1.932 & -0.816 \\
\hline CCR & 0.00013 & 0.00005 & -0.00005 & -0.00002 & 0.00001 & 0.00006 \\
\hline t-val. & 1.900 & 0.700 & -0.336 & -0.296 & 0.155 & 0.460 \\
\hline $\mathrm{R}^{2}$ & $12.31 \%$ & $9.43 \%$ & $11.38 \%$ & $9.82 \%$ & $11.82 \%$ & $11.91 \%$ \\
\hline Obs. & 518 & 518 & 518 & 522 & 522 & 522 \\
\hline \multicolumn{7}{|c|}{ A.2: Impact on FX Realized volatility } \\
\hline & \multicolumn{3}{|c|}{ First-move } & \multicolumn{3}{|c|}{ Additional-move } \\
\hline$|\Delta \mathrm{LCCR}|$ & $0.1849^{*}$ & -0.2072 & 0.0026 & 0.1562 & $-0.1826^{* *}$ & 0.1965 \\
\hline t-val. & 1.924 & -1.578 & 0.018 & 1.483 & -2.321 & 1.559 \\
\hline CCR & 0.00066 & -0.00257 & 0.00087 & 0.00445 & -0.00344 & 0.00491 \\
\hline t-val. & 0.150 & -0.621 & 0.173 & 1.137 & -0.845 & 1.060 \\
\hline $\mathrm{R}^{2}$ & $11.36 \%$ & $11.08 \%$ & $11.12 \%$ & $11.04 \%$ & $11.32 \%$ & $10.61 \%$ \\
\hline Obs. & 470 & 470 & 470 & 474 & 474 & 474 \\
\hline \multicolumn{7}{|c|}{ A.3: Impact on FX Option-implied volatility } \\
\hline & \multicolumn{3}{|c|}{ First-move } & \multicolumn{3}{|c|}{ Additional-move } \\
\hline$|\Delta \mathrm{LCCR}|$ & 0.0253 & -0.0010 & $-0.0671^{\text {*** }}$ & $-0.0165^{*}$ & 0.0149 & 0.0055 \\
\hline t-val. & 1.402 & -0.081 & -2.467 & -1.672 & 1.516 & 0.179 \\
\hline CCR & 0.00050 & -0.00033 & -0.00153 & -0.00008 & -0.00026 & 0.00018 \\
\hline t-val. & 0.873 & -0.521 & -1.582 & -0.125 & -0.454 & 0.207 \\
\hline $\mathrm{R}^{2}$ & $12.32 \%$ & $10.90 \%$ & $13.08 \%$ & $11.92 \%$ & $11.85 \%$ & $11.01 \%$ \\
\hline Obs. & 518 & 518 & 518 & 522 & 522 & 522 \\
\hline
\end{tabular}

Panel B: Impact on domestic equity markets

B.1: Impact on domestic equity cumulative abnormal returns

\begin{tabular}{|c|c|c|c|c|c|c|}
\hline & \multicolumn{3}{|c|}{ First-move } & \multicolumn{3}{|c|}{ Additional-move } \\
\hline$\triangle \mathrm{LCCR}$ & $0.0397^{* *}$ & 0.0034 & -0.0094 & 0.0203 & -0.0015 & 0.1129 \\
\hline t-val. & 2.203 & 0.262 & -0.564 & 1.170 & -0.070 & 1.467 \\
\hline CCR & -0.0002 & 0.0000 & -0.0004 & 0.0000 & -0.0001 & -0.0001 \\
\hline t-val. & -0.761 & -0.169 & -0.826 & -0.237 & -0.564 & -0.256 \\
\hline $\mathrm{R}^{2}$ & $12.36 \%$ & $10.32 \%$ & $10.30 \%$ & $11.47 \%$ & $10.79 \%$ & $18.51 \%$ \\
\hline Obs. & 460 & 460 & 460 & 460 & 460 & 460 \\
\hline
\end{tabular}

B.2: Impact on domestic equity volatility

\begin{tabular}{|c|c|c|c|c|c|c|}
\hline & \multicolumn{3}{|c|}{ First-move } & \multicolumn{3}{|c|}{ Additional-move } \\
\hline$|\Delta \mathrm{LCCR}|$ & $0.0149^{* * *}$ & $-0.0111^{* * *}$ & $0.0138^{* * * *}$ & $-0.0121^{*}$ & 0.0044 & 0.0204 \\
\hline t-val. & 3.386 & -3.051 & 3.804 & -1.692 & 0.544 & 1.522 \\
\hline CCR & 0.0000 & 0.0000 & 0.0001 & 0.0000 & 0.0000 & 0.0000 \\
\hline t-val. & 0.279 & -0.294 & 0.415 & -0.395 & 0.162 & 0.279 \\
\hline $\mathrm{R}^{2}$ & $11.17 \%$ & $10.95 \%$ & $10.93 \%$ & $10.15 \%$ & $10.19 \%$ & $10.04 \%$ \\
\hline Obs. & 446 & 446 & 446 & 446 & 446 & 446 \\
\hline
\end{tabular}

This table reports the average values from 10,000 estimations of Equations (19) - (20) with Huber-White robust standard errors. Only downgrades of issuers on negative outlook/watch are used for this table. *, $* *, * * *$ denote significance at the $10 \%, 5 \%, 1 \%$ levels. 